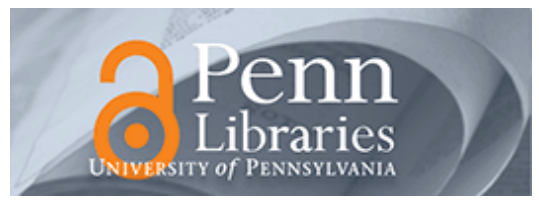

University of Pennsylvania

ScholarlyCommons

Accounting Papers

Wharton Faculty Research

$4-2008$

\title{
The Power of the Pen and Executive Compensation
}

John E. Core

Wayne R. Guay

University of Pennsylvania

David F. Larcker

Follow this and additional works at: https://repository.upenn.edu/accounting_papers

Part of the Accounting Commons, Business and Corporate Communications Commons, Corporate

Finance Commons, and the Finance and Financial Management Commons

\section{Recommended Citation}

Core, J. E., Guay, W. R., \& Larcker, D. F. (2008). The Power of the Pen and Executive Compensation. Journal of Financial Economics, 88 (1), 1-25. http://dx.doi.org/10.1016/j.jfineco.2007.05.001

This paper is posted at ScholarlyCommons. https://repository.upenn.edu/accounting_papers/116

For more information, please contact repository@pobox.upenn.edu. 


\title{
The Power of the Pen and Executive Compensation
}

\begin{abstract}
We examine the press' role in monitoring and influencing executive compensation practice using more than 11,000 press articles about CEO compensation from 1994 to 2002. Negative press coverage is more strongly related to excess annual pay than to raw annual pay, suggesting a sophisticated approach by the media in selecting CEOs to cover. However, negative coverage is also greater for CEOs with more option exercises, suggesting the press engages in some degree of "sensationalism." We find little evidence that firms respond to negative press coverage by decreasing excess CEO compensation or increasing CEO turnover.
\end{abstract}

\section{Keywords}

press, media, executive compensation, corporate governance

Disciplines

Accounting | Business and Corporate Communications | Corporate Finance | Finance and Financial Management 


\title{
The Power of the Pen and Executive Compensation
}

\author{
John E. Core \\ The Wharton School \\ University of Pennsylvania \\ Philadelphia, PA 19104-6365 \\ Wayne Guay* \\ The Wharton School \\ University of Pennsylvania \\ Philadelphia, PA 19104-6365 \\ David F. Larcker \\ Graduate School of Business \\ Stanford University \\ Stanford, CA 94305-5015
}

\begin{abstract}
We examine the press' role in monitoring and influencing executive compensation practice using more than 11,000 press articles about CEO compensation from 1994 to 2002. Negative press coverage is more strongly related to excess annual pay than to raw annual pay, suggesting a sophisticated approach by the media in selecting CEOs to cover. However, negative coverage is also greater for CEOs with more option exercises, suggesting the press engages in some degree of "sensationalism." We find little evidence that firms respond to negative press coverage by decreasing excess CEO compensation or increasing CEO turnover.
\end{abstract}

Revised: May 23, 2007

* Corresponding author. Tel: 215-898-7775; fax: 215-573-2054; email: guay@wharton.upenn.edu. We thank Greg Miller, seminar participants at Stanford University, and an anonymous referee for their helpful comments. We also thank Jihae Wee for excellent research support, and appreciate financial support from the Wharton School of the University of Pennsylvania and the Graduate School of Business at Stanford University. 


\section{The Power of the Pen and Executive Compensation}

\section{Introduction}

With the possible exception of major accounting frauds (e.g., WorldCom, Enron, etc.), there are few topics that are more pervasive and produce bigger headlines in the business press than executive compensation. The debate about executive compensation tends to focus on the overall level of compensation (e.g., relative to workers in the U.S. or to executives in other countries), the rate of increase (e.g., relative to inflation or stock price returns), and the form of payment (e.g., stock options). Although there is extensive academic research on the determinants of executive compensation, there is little empirical evidence on the role of the popular and business press as a potential monitor of executive pay (e.g., see Zingales, 2000; Bebchuk and Fried, 2004).

The objective of our study is to provide insight into three questions: (1) What decision model does the media use to select chief executive officers (CEOs) for coverage about their compensation, (2) What determines the proportion of that coverage that is negative-toned, and (3) Do firms and managers find this attention sufficiently costly that they respond by making changes to their compensation or employment practices? Empirical evidence on these research questions provides insight into the role of the press in monitoring and influencing executive compensation practice.

We examine a large sample of ExecuComp CEOs and an extensive collection of more than 11,000 press articles about CEO compensation from 1994 to 2002. Using an iterative key word search procedure, we partition the press articles based on whether they have a negative tone. Thus, for each CEO, in each year, we obtain a measure of the number of compensation 
articles and the fraction of these articles with a negative tone. We use this data to provide evidence on the press' decision model and on the effect of press coverage on firms' actions.

Not surprisingly, the press chooses to cover CEOs with high total annual pay. We also find that in deciding which CEOs to cover, the press does not appear to discriminate between CEOs that receive high expected pay versus CEOs that receive high excess pay, where excess pay is the residual from an expected compensation model that controls for standard economic determinants. Further, CEOs at large firms and firms with poor operating performance are also more likely to be selected for coverage.

Conditional on the press deciding to cover a CEO's compensation, we find that negative coverage is more strongly related to measures of excess total annual pay than to raw total annual pay. We interpret this result as evidence that the press uses a relatively sophisticated approach when writing negative articles about CEO compensation. On the other hand, we also find that negative coverage is related to the CEOs' proceeds from option exercises. This latter finding is consistent with Holmstrom and Kaplan's (2003) concern that one of the reasons the press portrays executive pay as a "runaway train" is that it misinterprets the payoff from exercised options as being a component of annual pay. In fact, the grant date value of options, not the payoff at exercise, is widely considered the more appropriate measure of option pay. ${ }^{1}$

We find little support for the hypothesis that the press serves as a catalyst or change agent for CEO compensation practices. Specifically, there is no consistent evidence that total compensation decreases after CEOs receive negative press coverage, and we find no evidence that negative press coverage of CEO compensation is related to CEO turnover. Thus, our results

\footnotetext{
${ }^{1}$ It is possible that the press justifiably writes negative articles about CEOs with large realized option payoffs if the magnitude of option exercises reflects a measure of cumulative excess compensation over a period of time.
} 
do not corroborate recent evidence that the media exerts an important influence on corporate governance choices (e.g., Dyck and Zingales, 2002, 2004; Louis, Joe and Robinson, 2004).

The remainder of the paper consists of four sections. Section 2 provides a literature review and develops our research questions. Section 3 describes the sample selection and measurement choices. The results are presented in Section 4, and summary conclusions are provided in Section 5.

\section{Background and Research Questions}

\subsection{Determinants of media attention about CEO compensation}

Although there is considerable discussion about the role of disclosure and transparency in monitoring managerial behavior, the precise mechanisms for disclosing and disseminating information have received limited attention in the academic literature (Zingales, 2000). Dyck and Zingales (2002) argue that this limited attention stems from the small role that the diffusion of information plays in agency models. ${ }^{2}$ They argue that the media is one vehicle through which information is aggregated and credibly communicated to the public (and across firms). Thus, the media can play a substantial role in reducing the costs of contracting parties for collecting and evaluating information, and in shaping the reputation of contracting parties.

In order to provide insight into these questions, it is necessary to identify the objective function of the media. As suggested by Jensen (1979), the approach to modeling the media industry is similar to any industry and begins with analyzing the demand faced by news producers (e.g., newspapers, magazines, etc.) and the supply of news received by these producers. Dyck and Zingales (2002) and Miller (2006) argue that there is a consumer demand

\footnotetext{
${ }^{2}$ In the accounting literature, diffusion of information plays a large role in research on the quality of accounting information disclosed by management to its shareholders, or in theoretical agency models incorporating channels of communication. However, there is little work on intermediaries, such as the press, that filter firm disclosures and disseminate information to the general stockholding public.
} 
for the investigative reporting role of the media, and Zingales (2000) hypothesizes that readers rely on this reporting to form opinions only when they believe the information provided to be accurate and reliable. In contrast, Jensen (1979) takes a more skeptical view of the media and suggests that most of the demand for news services derives not from a demand for information, but from a demand for entertainment. Since the news media's competition under this scenario is sitcom television and tabloids, the media is expected to sensationalize news stories. Jensen further argues that the media will tailor news stories to take a negative tone about individuals that are out of favor with public opinion (e.g., CEOs who are paid much more than their peers, or who have laid off large numbers of employees).

Miller (2006) provides some initial empirical results that are broadly consistent with both of the above sources of demand for publicity. He examines a sample of 263 cases of Securities and Exchange Commission (SEC) Accounting and Auditing Enforcement Releases to investigate whether the press is a watchdog for accounting fraud. Consistent with information provision, Miller finds that the media provides the public with information about accounting fraud. However, consistent with sensationalism, he also finds that the media is more likely to fill the watchdog role for firms with a larger public following, firms with a richer information environment, and where the story is more likely to be sensational and interesting to the public. Miller also examines whether coverage is less negative for firms that do more advertising, but his results do not support this interesting proposition.

Media coverage of executive compensation potentially satisfies both of the demand functions identified above. Multi-million dollar pay packages, and the potential scandals surrounding the wealthy individuals who receive high pay, can be very entertaining. For example, there were repeated references, and many negative references, in the press about Tyco 
International's purchase of a $\$ 6,000$ shower curtain for CEO Dennis Kozlowski's corporate apartment. Similarly, there were repeated references, and many negative references, about the extensive perquisites paid to General Electric's CEO, Jack Welch, that were disclosed in divorce proceedings after his retirement.

On the other hand, if readers of the press demand media coverage about executive compensation that provides reliable information about potential governance problems, we expect that the media will identify and cover individuals who have "excessive" pay. That is, under this hypothesis, the media will not focus simply on large pay. Nor will it focus on large single components of pay such as stock option grants and cash payouts from bonus plans, or on large option exercises. Excess pay, defined as observed compensation less a measure of expected compensation derived from standard economic determinants, is known to be a sign of poor governance (e.g., Core, Holthausen and Larcker, 1999), and poor governance is clearly an important issue for shareholders, employees, suppliers, and society at large. Under this hypothesis, the media will not focus simply on large total pay (or option exercises) because it recognizes that large pay packages are optimal in settings where they reflect the quality, performance, or bargaining power of the CEO. Thus, we predict that the media makes adjustments to a given CEO's pay level to control for "normal" or "reasonable" pay, and that coverage of excess pay will primarily have a negative tone. We test this prediction with the following hypothesis:

$\mathbf{H}_{\mathbf{1}}$ : Negative media coverage of CEO compensation is positively related to excess pay.

However, if the primary source of demand is not from consumers seeking reliable information, but instead from consumers seeking entertaining news about highly paid executives, we expect that the media will sensationalize its stories. The press may satisfy this demand by 
writing negative articles about executives with high pay, regardless of whether circumstances are such that the high pay is reasonable. In this case, we view the negative coverage as "sensationalism," and predict that negative press coverage is positively related to total pay without making adjustments for an expected level of pay given the CEO's ability and performance. This sensationalism viewpoint provides a contrasting perspective to the "informing the public" notion underlying Hypothesis 1. Specifically, the press is predicted to provide negative coverage of high total pay (which is composed of expected pay given firm and CEO characteristics, plus excess pay). We propose the following hypothesis to test the "sensationalism" prediction:

$\mathbf{H}_{2}$ : Negative media coverage of CEO compensation is positively related to total pay (i.e., related to both expected pay and excess pay).

Economists generally view the grant value of stock options as a more appropriate measure of CEO option-based pay than ex post realized proceeds from multi-year grants. For example, consider a CEO who is granted stock options each year for five years. If this CEO chooses to exercise all of these options in the fifthyear, it would inappropriate to infer that the CEO received no option compensation in the first four years when the options were granted, and substantial option compensation only in the fifth year when the options are exercised. However, exercise proceeds are a simple-to-understand, and easy-to-compute, measure of the value realized by executives from options. And, in fact, a measure of total payout that includes option exercises rather than option grants is frequently cited in pay surveys in the financial press (e.g., see Forbes's annual rankings of highest paid CEOs). ${ }^{3}$ A sensationalism perspective (or possibly

\footnotetext{
${ }^{3}$ Executive bonuses are generally measured in compensation studies at payout values rather than ex ante values. Ideally, one would measure both option pay and bonus pay at the grant date expected value of the pay. However, although data are readily available to estimate grant date option values, it is difficult to estimate the expected value to the executive from a given bonus plan.
} 
just naïveté) suggests that the press may not discriminate between the CEO's annual pay and large dollar proceeds realized by CEOs from options. To examine this hypothesis, we test the following:

$\mathbf{H}_{3}$ : Negative media coverage of CEO compensation is positively related to large dollar amounts realized from stock option exercises.

In addition to our analysis of negative coverage of CEO compensation, we also examine general press coverage of compensation in order to distinguish the decision of the press to cover a story from the choice to produce a story with a negative tone. We do not formulate specific hypotheses about general coverage of pay, but rather include these results to provide descriptive evidence on how the press chooses which CEOs to cover. We view the role of non-negative coverage of compensation as being somewhat unclear. For example, general coverage of total pay (both expected and excess compensation) might be informative for corporate governance purposes by providing benchmarks against which to compare CEO pay across firms. However, general coverage of total pay might be consistent with sensationalism, where readers find articles about wealthy CEOs to be entertaining, and are not particularly concerned about whether their pay level is expected or excessive.

\subsection{Influence of the media on CEO compensation}

Dyck and Zingales (2002) argue that there are at least three ways in which media attention can affect the reputations of firms and their officers and directors, and play a role in corporate governance. First, media attention on firms with weak corporate governance can drive politicians and regulators to enact legislation to reform or enforce corporate law, especially if they believe that failure to do so would hurt their political careers or cause public outcry. The recent media attention given to stock option backdating, and the consequent regulatory interest, 
could be thought of as an example of this type of activity. ${ }^{4}$ Second, negative media attention on managers and directors can call into question whether these individuals are good decision makers who attend to the interests of their shareholders and employers. Fama and Jensen (1983) make a similar argument that the value of managers' and directors' human capital depends primarily on signals about their performance as decision makers within corporations. Thus, if negative media attention damages managers' and directors' reputations, it can reduce the value of these individuals in the labor market. Finally, Dyck and Zingales (2002) argue that negative media attention can hurt the reputations of managers and directors within their communities and impose social costs on both them and their families. ${ }^{5}$ Dyck and Zingales (2002 and 2004) also provide evidence in an international setting that the media plays a role in corporate governance and influences firms' behavior. Their primary findings are that the private benefits of control are smaller and the responsiveness of the private sector to environmental issues is greater in countries with larger newspaper circulation.

Two additional papers are related to our research question. Johnson, Porter and Shackell (1997) examine changes in compensation from 1993 to 1994 for a sample of 186 CEOs to investigate whether CEO compensation is sensitive to stakeholder pressure. They find that the existence of a negative tone article in any one of five leading periodicals is associated with a smaller increase in total CEO pay from 1993 to 1994 and an increase in the sensitivity of cash pay to firm performance. However, as we demonstrate in Section 4.2, this finding is confounded by strong mean reversion in pay among the general population of highly paid CEOs (i.e., when a

4 For example, see and Heron and Lie (2007). Also see the Wall Street Journal online at: http://online.wsj.com/public/resources/documents/info-optionsscore06-full.html, which lists corporations that have come under SEC and Justice Department scrutiny for possible option backdating. We last accessed this website on February 23, 2007.

${ }^{5}$ In our study, we do not distinguish between these three channels of media influence. For our purposes, it is only important that negative media attention about CEO compensation can impose costs on firms and their CEOs. 
CEO has high pay in year $t$, there is a natural tendency for pay to be lower in year $t+1$ ). Moreover, highly paid CEOs are also more likely to receive media attention. Therefore, CEOs that draw media attention are more likely to experience mean reversion in pay, but this relation may not be causal. Finally, Louis, Joe and Robinson (2004) provide some evidence that negative Business Week coverage regarding institutional investors' assessment of board effectiveness influences boards' actions. In particular, the boards identified as worst are more likely to replace CEOs and board chairs, to separate the CEO and chair functions, and to increase the number of outside board members. However, it is not clear from these findings whether the boards' actions are due to media coverage or due to pressure from unsatisfied institutional investors.

If negative media coverage damages the reputations and human capital of managers and directors, firms will respond to this negative coverage by taking steps to avoid further coverage in the future. However, the nature of the responses that the firms might take is not clear. If the media acts as a good watchdog over executive pay, and if its negative coverage primarily serves to provide investors and the public at large with reliable information about excess pay, we expect firms to respond by reducing excess CEO pay. ${ }^{6}$ An even more severe response would be to terminate the $\mathrm{CEO}$ to avoid future negative media coverage of that $\mathrm{CEO}$ and his compensation. To gain insight into the outcomes of negative media coverage, we test the following hypotheses:

$\mathbf{H}_{4}$ : CEO compensation declines following negative media coverage.

$\mathbf{H}_{5}$ : CEO turnover increases following negative media attention.

As noted above, it is also possible that the media's coverage of CEO pay serves to entertain readers with sensational stories. In this case, we expect that firms either take no action (and bear the brunt of any reputation damage) or make "cosmetic" adjustments to avoid negative

\footnotetext{
${ }^{6}$ As we discuss below, firms will respond to unanticipated negative coverage by reducing future pay. To the extent that firms anticipate the costs of negative media coverage, they will reduce current pay to avoid these costs.
} 
media attention in the future. An example of a "cosmetic" change would be for the CEO to alter the pattern of his stock option exercises. If the media sensationalizes compensation stories by including the proceeds from option exercises in the computation of executive pay, CEOs may avoid exercising options for a few years or "smooth out" option exercises after the negative publicity. We test the following research hypothesis:

$\mathbf{H}_{6}$ : Option exercises decline following negative media attention.

\section{Sample Selection and Variable Measurement}

Our initial sample consists of all ExecuComp CEOs from fiscal years 1993 to 2001. For a CEO to be included in the final sample, we require that we can match the firm to the CRSP database, that CEO tenure is available in ExecuComp, and that the CEO is in office at the end of the fiscal year. Second, we require non-missing data on CEO compensation and on the variables that we use to estimate our model for excess compensation and press coverage (described below). Finally, we require that the firm name and CEO name can be matched to the Factiva news source database. ${ }^{7} \quad$ These data requirements yield a sample of 12,090 CEO-year observations from 1993 to 2001. The sample contains 3,126 different CEOs at 2,052 different companies.

The summary results in Table 1 show that the number of CEOs in the sample grows slightly over time (as ExecuComp coverage increases). Consistent with other findings using ExecuComp data (e.g., Hall and Murphy, 2002), we find that CEO total compensation increases substantially over the period, and at a greater percentage growth rate than firm sales. In addition, there is a monotonic increase in the average level of total press coverage of CEO pay and in the

\footnotetext{
${ }^{7}$ Factiva is a joint venture between Dow Jones and Reuters.
} 
proportion of CEOs who receive coverage. However, conditional on receiving coverage, the proportion of coverage that is negative is relatively constant over time (we describe the measurement of these publicity variables below).

\subsection{Measurement of press coverage and negative press coverage}

We measure publicity about CEO compensation by gathering all articles related to the CEO's compensation from the Factiva database in the fiscal year after the compensation was earned (for example, for a firm with a fiscal year ending June 30, 2001, where CEO compensation is typically disclosed in the proxy statement in August or September of 2001, we would match articles published during the next fiscal year ended June 30, 2002). We include all major news and business publication sources on Factiva with the exception of the press release wires through which firms initiate the release of information, such as PR Newswire, FD Newswire, and Business Wire. Similar to Francis, Huang, Rajgopal and Zang (2004), we use the company identifier in Factiva to locate articles covering a specific firm. We then locate articles written about the CEO's compensation through the following search:

(CEO NAME or CEO NAME'S) near20 (compensation or salary or bonus or option* near10 grant or option* near10 receiv* or option* near10 exercis* or restricted stock or (pay near5 00) or (was paid near5 00) or (pay near5 million*) or (was paid near5 million*)) and (CEO NAME or CEO NAME'S) same (compensation or salary or bonus or option* near10 grant or option* near10 receiv* or option* near10 exercis* or restricted stock or (pay near5 00 ) or (was paid near5 00 ) or (pay near5 million*) or (was paid near5 million*))

The objective of this free text search is to identify all articles in which the CEO's compensation is described in either a positive, negative, or neutral fashion. ${ }^{8}$ We count each article as a single observation, regardless of the number of times a CEO's name or compensation is mentioned in the article.

\footnotetext{
${ }^{8}$ As described in the Factiva Inside-Out Reference Guide, "near20" locates words within 20 words of the CEO's name and "same" locates words in the same paragraph as the CEO's name.
} 
To measure negative publicity about CEO compensation, we iteratively develop a Perl program to process the text of each article about CEO compensation to assess whether the article has a negative tone. The input into the Perl program consists of a set of negative tone keywords and phrases. This set of keywords and phases was developed from manually reading approximately 200 articles about CEO compensation, where the articles included both randomly selected firms and firms widely known to have received negative publicity (e.g., Tyco International and Citigroup). ${ }^{9}$

In order to validate and improve the Perl algorithm, we applied the search string to

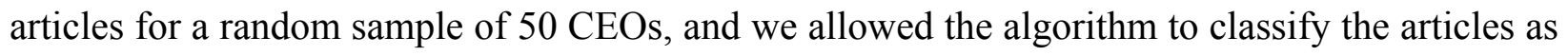
having either a negative or non-negative tone. We then read these same articles and manually assigned each as having either a negative or non-negative tone. To identify errors in the Perl algorithm, we compared the two sets of coded negative tones using a contingency table of manual partitioning versus computer partitioning. Based on the classification errors, we adjusted the keyword search to improve the fit of the search string within this 50 CEO sample.

To check the validity of these adjustments, we applied the improved negative tone Perl algorithm string to articles for an independent random sample of 50 CEOs. We again read and partitioned the articles for this second random sample and constructed another contingency table to assess accuracy. This manual partitioning identified $18 \%(82 \%)$ of the articles as negative tone (non-negative tone). The automated Perl keyword search correctly identified $75 \%$ of the nonnegative tone articles and $54 \%$ of the negative tone articles. Further, the manual partitioning identified $25 \%(75 \%)$ of the firm-years as having at least one negative tone article (no negative

\footnotetext{
${ }^{9}$ As illustrated in Appendix A, the final negative tone search string consists of approximately 150 keywords and phrases, such as "high pay", "excess pay", and "generous options". For most of the phrases, we allow for the possibility that the keywords do not immediately precede or follow each other, and may be several words apart in the text. We also allow for different characterizations of the same word (e.g., "large bonus", "larger bonus", "and largest bonus").
} 
tone article). The Perl algorithm correctly identified $63 \%$ of the firm-years without negative tone articles and $77 \%$ of the firm-years with negative tone articles. The fact that the classification rates are less than $100 \%$ confirms that there is measurement error in our search string (in Section 4.1, we show in sensitivity analysis that this measurement error does not appear to affect our inference). We use the revised search string to identify negative tone articles for the full sample of CEO compensation articles ("NEGATIVE"). Appendix A shows our final negative tone search string.

In order to provide some descriptive information about our search string, Appendix B contains excerpts from two articles about the 2001 compensation package for E*Trade Financial Corp.'s CEO, Christos Cotsakos. Both articles were published on May 1, 2002. The first article from The New York Times reports the salary, bonus, equity, and other components of Cotsakos' pay package without taking a view as to whether the pay package is excessive or unreasonable. We classify this article as having a non-negative tone. The second article from The Wall Street Journal also reports the components of Cotsakos' pay package but takes a negative tone by calling the compensation an "outsize package" and referring to Cotsakos as the "highest-paid CEO on Wall Street." The keyword "outsize" within a few words of "salary" and/or "bonus," and the keyword "highest" within a few words of "pay" are both triggers for our keyword search that classify this article as having a negative tone. However, note the title of the second article, "No Discount: E*Trade CEO Gets Pay Deal Of $\$ 80$ Million." Although this title clearly has a negative tone, the "play on words" nature of the text prevents us from flagging this title as negative tone with our Perl search string. In this case, the body of the article is sufficient to categorize the article as negative tone. We acknowledge that it is difficult to construct a completely accurate search string and that our negative tone classification inevitably measures 
true negative tone with error. However, a sensitivity analysis summarized below in Section 4.1 suggests that our inference using the negative publicity measure in the full sample is not induced by measurement error.

The time-series statistics on the number of compensation-related articles for our sample CEOs over the period 1994 to 2002 is reported in Table 2 (Panel A). ${ }^{10}$ The number of compensation-related articles grew rapidly from 325 to 3,263 (Column 3), an increase of about $900 \%$. However, at the same time, the total number of articles across all topics grew from 216,677 to 825,887 (Column 1), an increase of about $280 \%$. Similarly, the number of news sources covering CEO compensation grew from 62 to 470 (Column 2), a rise of about 660\%. To explore whether the growing number of compensation-related articles is primarily due to the growth in the number of articles and sources, we present time-series data for The Wall Street Journal, one of the largest sources. As might be expected, The Wall Street Journal released a growing number of compensation-related articles over this period. The total number of articles for this source was 210 in 2002 compared to 58 in 1994 (Column 5), an increase of about 260\%. Thus, the increase in articles does not appear to be simply caused by the increase in sources covered by Factiva.

The fraction of negative tone compensation articles across all sources has remained a fairly constant fraction of total articles, with a yearly average of about 33\% (Column 4). The last column in Table 2 (Panel A) shows that a somewhat larger fraction of the compensation articles written by The Wall Street Journal are negative, with a yearly average of about $38 \%$. This suggests that some news agencies, as a matter of strategy or reporting orientation, are more likely than others to publish compensation articles with a negative tone.

\footnotetext{
${ }^{10}$ Since our sample data on CEO compensation covers the time period from 1993 to 2001, the articles for the year following the compensation are collected from 1994 to 2002.
} 
To explore compensation coverage across news sources, we tabulate article counts separately for many of the major sources in Table 2 (Panel B). We classify major news sources as newswires, newspapers, or magazines. The main newswires, Associated Press, Dow Jones and Reuters, provide the greatest number of compensation-related articles, but have the lowest fraction of negative tone compensation articles, at about $22 \%$. This latter finding is perhaps not surprising given that newswires tend to capture company press releases. The major newspapers (The Wall Street Journal, The New York Times, Financial Times, etc.) supply the second highest fraction of negative tone articles, at $36 \%$. The largest fraction of articles with a negative tone, at about $47 \%$, is written by magazines (Fortune, Business Week, etc.). This ranking of negative tone coverage potentially reflects a greater tendency by the papers and magazines to sensationalize stories in order to sell copies, presumably due to differences in their subscriber base and marketing techniques.

In the first two rows of Table 3, we provide descriptive data on compensation-related articles by CEO-year. In this table, and in our data analysis in Tables 6 to 9 , we mitigate the influence of outliers by setting the upper- and lower-most percentiles for our variables equal to the values at the $1^{\text {st }}$ and $99^{\text {th }}$ percentiles in each year, respectively. Media coverage is skewed, with the median CEO receiving no articles about his compensation in a given year. In $21.6 \%$ of the CEO-years, at least one article was published about the CEO's compensation, and the ten percent of the CEO-years with the greatest media coverage received at least two articles. Negative media coverage is skewed to an even greater extent, with only $10.0 \%$ of the CEO-years receiving at least one compensation article with a negative tone. In one percent of the CEOyears, at least four negative tone articles were written about the CEO's compensation. For the 2,607 observations in which the CEO has some coverage of his compensation, $47 \%$ of the CEOs 
have at least some negative-toned coverage, and $28 \%$ of the compensation articles have a negative tone.

\subsection{Control variables and model of expected press coverage}

Our main objective is to better understand the determinants of press coverage about executive compensation, and in particular, negative coverage about executive compensation. The results in Tables 1 and 3 reveal that only a subset of CEOs attracts press coverage on their reported compensation. Among the CEOs that attract coverage, there is substantial variation in the degree of negative comments about their pay, as proxied by the proportion of the coverage that is negative. To address this empirically, we first model the media's choice of whether to cover a CEO with the following probit model:

$$
\mathrm{E}\left[\operatorname{Prob}\left(\text { Coverage }_{\mathrm{it}+1}\right)\right]=\Phi\left(\gamma_{\mathrm{o}}+\gamma_{1} \text { Compensation }_{\mathrm{it}}+\gamma_{2} \text { Controls }\right)
$$

For those CEOs who receive coverage, we model the proportion of the coverage that is negative with the following general linear model:

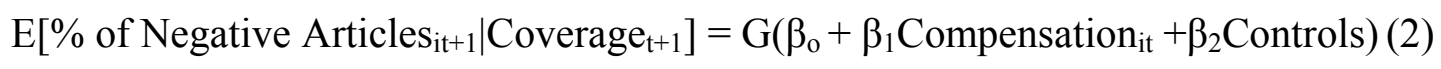

The dependent variable in equation (2) is a fraction bounded between 0 and 1 . We follow Papke and Wooldridge (1996) and estimate equation (2) using a general linear model (GLM) in which the link function is logistic. Papke and Wooldridge show that this estimator is consistent when the dependent variable is a proportion ranging from 0 to 1 , and when there may be a mass of observations at 0 and $1 .^{11}$

\footnotetext{
${ }^{11} \mathrm{We}$ obtain the same inference if we instead estimate a linear model for the fraction using OLS. If we estimate an OLS model for the fraction and include a Heckman (1979) correction for the predictability of the coverage decision in equation (1), we obtain the same inference. The Heckman correction is not significant in any of our models, which suggests that results are robust to ignoring the selection in the second-stage model.
} 
We note that in these models, coverage and negative coverage are measured in the fiscal year $\mathrm{t}+1$ following determination of compensation in year $t^{12}$ This lessens the chance of a simultaneity bias, in which realized negative coverage causes reductions in realized pay. However, as we discuss further below, if firms anticipate that future negative coverage can be very costly, they may reduce current pay in order to avoid future coverage.

We expect that publicity about CEO pay derives not only from the magnitude and components of CEO pay, but also from general determinants of press coverage. Therefore, we control for the determinants of publicity that are not directly related to CEO compensation. To our knowledge, an accepted model for the expected level of press coverage related to CEO pay does not exist. As a starting point, we include log(Number of Firm Articles) as a control variable for general firm-specific press coverage across all topics, where $\log ($ Number of Firm Articles) is measured for each firm-year as the natural logarithm of the total number of articles that mention the firm across all major news and business publication sources on Factiva, excluding newswires that primarily carry company-initiated disclosures. ${ }^{13}$ We also expect that firm size is a key determinant of publicity (see Jensen, 1979; Miller, 2006). Press coverage of large firms will have broader appeal as these firms are more likely to be household names and to have larger customer and shareholder bases. At the same time, large firms may be able to impose costs on media firms that cover them in a negative light. These costs may come in the form of withholding valuable news stories or withholding advertising dollars. ${ }^{14}$ We use two variables to control for firm size

\footnotetext{
${ }^{12}$ Base salary, option and restricted stock grants, and the majority of compensation are determined and paid during the fiscal year. The one exception is cash bonuses, which are determined early the next fiscal year after results are known. However, the bonus amounts tend to be small compared to option and restricted stock grants.

${ }^{13}$ In the 68 firm-years with no articles on Factiva, we set Number of Firm Articles equal to one to avoid losing the observations.

${ }^{14}$ The costs of withholding valuable news from the press may apply not only to large firms but also to growing firms with rich information environments that are engaging in substantial investments, acquisitions, or product
} 
and likelihood of broad appeal: the logarithm of each firm's sales revenues ("Sales") and membership in the S\&P 500 ("S\&P500").

Jensen (1979) argues that the media is more likely to write a negative article when the individual under scrutiny has lost popularity with the public. We include recent firm performance in our regressions to control for the possibility that the CEO has fallen out of favor with the public. We measure firm performance using contemporaneous and lagged stock returns obtained from CRSP ("RET”) and accounting performance obtained from Compustat (“ROA") which is computed as net income before extraordinary items divided by average assets). To allow for the possibility that press coverage is more sensitive to negative performance than to positive performance, we include separate variables for negative ("NEG”) and positive ("POS") stock return and accounting performance. ${ }^{15}$ We also include CEO tenure ("Tenure") as a control variable because we expect that it may take time for the press to become interested in covering a new CEO. Finally, we expect that press coverage varies across different calendar years and sectors of the economy. To capture this effect we include indicator variables for two-digit SIC code and calendar year in our model.

\subsection{Measurement of compensation variables and excess compensation}

As described in Section 2, we expect that publicity may be influenced by total annual compensation. We measure Total Comp as the sum of salary, bonus, long-term incentive plan payouts, the value of restricted stock grants, the value of options granted during the year, and any

\footnotetext{
developments. At the same time, growth firms may also have broader appeal to the public than stable or declining firms. Our regressions are robust to including book-to-market as a control variable for firm's investment opportunities.

${ }^{15}$ Dial and Murphy (1995) raise the possibility that unpopular operational decisions draw media attention. For example, in their case study of General Dynamics, the press strongly criticized the CEO for receiving a bonus payout after the stock price responded positively to his decision to lay off thousands of employees. We examine this possibility in Section 4.3.
} 
other annual pay. This is the most common measure of total pay in the academic literature. We hypothesize in Hypothesis 3 that press coverage could also be affected by realized option exercise proceeds as opposed to option grant value. To test this hypothesis, we construct a measure of total realized payouts to the CEO, Total Payout, computed as the sum of salary, bonus, long-term incentive plan payouts, value of restricted stock grants, proceeds from options exercised during the year, and any other annual pay. This measure of total realized payout is common in the media (e.g., see Forbes's annual rankings of highest paid CEOs). ${ }^{16}$ We obtain our compensation data from ExecuComp.

Descriptive statistics for the compensation variables are presented in Table 3. The mean Total Comp is $\$ 3.7$ million, and the mean Total Payout is $\$ 3.1$ million. However, the values in the extreme percentile of Total Payout are somewhat greater than those for Total Comp.

In addition to these raw compensation variables, we also construct a measure of excess CEO compensation to investigate whether the media appears to make adjustments for a "normal" level of compensation when writing an article with a negative tone. We measure excess compensation as actual compensation minus expected compensation. Our benchmark model for expected compensation follows prior research in this area (e.g., Smith and Watts, 1992; Core, Holthausen and Larcker, 1999; and Murphy, 1999), and is obtained by regressing the natural logarithm (Log) of compensation on proxies for economic determinants of CEO compensation, such as firm size, growth opportunities, stock return, accounting return, and industry controls:

$$
\log \left(\text { Compensation }_{\mathrm{it}}\right)=\alpha+\mathrm{x}_{\mathrm{it}} \beta+\mathrm{u}_{\mathrm{it}}
$$

where Compensation $_{\mathrm{it}}$ is Total Comp or Total Payout as described in Section 3.3, and $\mathrm{x}_{\mathrm{it}}$ consists of $\log (\text { Tenure })_{i t}, \log (\text { Sales })_{i t-1}, \mathrm{~S} \& \mathrm{P} 500_{\mathrm{it}-1}$, Book-to-market $_{\mathrm{it}-1}, \mathrm{RET}_{\mathrm{it}}, \mathrm{RET}_{\mathrm{it}-1}, \mathrm{ROA}_{\mathrm{it}}, \mathrm{ROA}_{\mathrm{it}-1}$,

\footnotetext{
${ }^{16}$ Total Payout also has preferable econometric properties as compared to using only the proceeds from option exercises. Specifically, an option exercise variable has a large mass at zero, whereas Total Payout has a positive value for all cases.
} 
and Industry controls $\mathrm{it}_{\mathrm{it}}$. Book-to-market is (book value of assets) / (book value of liabilities + market value of equity), and the other independent variables are defined above. We estimate equation (3) using ordinary least squares. We estimate Expected Compensation by exponentiating the expected value of equation (3).

We compute Residual(Compensation) by estimating expected Compensation and subtracting it from Compensation:

Residual $\left(\right.$ Compensation $\left._{\text {it }}\right)=$ Compensation $_{\text {it }}-$ Expected Compensation $_{\text {it }}$.

We compute \%Residual Compensation as:

$\%$ Residual $\left(\right.$ Compensation $\left._{\mathrm{it}}\right)=\log \left(\right.$ Compensation $\left._{\mathrm{it}}\right)-\log \left(\right.$ Expected Compensation $\left._{\mathrm{it}}\right)(5)$

Although we estimate equation (2) using annual cross-sectional regressions, in the interest of brevity, we present the results of a pooled cross-section, time-series estimation of equation (2) with year indicators in Table 4. Consistent with prior research, we find that all measures of compensation exhibit the expected positive associations with firm size, growth opportunities, and stock returns. The coefficient estimates for the annual regressions are substantively similar to those reported in Table 4.

\subsection{Illustrations from the sample}

Table 5 (Panel A) lists the ten CEOs with the greatest amount of coverage (i.e., greatest number of articles) about their compensation in any given year during our sample period. The compensation and firm characteristic variables are provided for the year prior to the press coverage variables (thus, the year $\mathrm{t}+1$ designation on the press variables). These CEOs had between 87 and 320 compensation-related articles, as well as very substantial negative press coverage, as measured by either fraction of articles that are negative, or number of articles that 
are negative. The percentage of negative articles in this group of CEOs ranges from $32 \%$ to $73 \%$, whereas the sample average is $28 \%$ (see Table 3 ).

CEOs with a large number of compensation-related articles tend to manage large, poor performing firms. Seven out of the ten firms have market capitalization of \$20 billion or more, and three-year market-adjusted returns are negative for all of the ten firms. Dennis Kozlowski of Tyco International received the most compensation-related articles in 2002 with 320, as well as the most negative articles (57\% or 183 negative articles). His total compensation in 2001 was $\$ 77.8$ million with substantial estimated excess compensation. ${ }^{17}$ Five of these ten CEOs had positive excess total pay in the year prior to the publicity. However, excess compensation during the prior year was not the obvious instigator of the press coverage for some of these CEOs. For example, Sanford Weil, CEO of Citigroup, received 178 compensation-related articles (40\% of which were negative), but had negative excess total pay. At the same time, Mr. Weil had a combination of fairly large raw compensation at $\$ 16.6$ million, substantial option exercises, poor three-year market-adjusted stock return performance $(-44 \%)$, and a history of prior media attention for being among the higher paid CEOs. Similarly, Carly Fiorina, CEO of Hewlett Packard, received 168 articles in 2002 (32\% of which were negative), but had lower than expected pay in 2001. However, although she had negative excess compensation, Ms. Fiorina was the recipient of considerable criticism about Hewlett Packard's sub-par performance as evidenced by Hewlett Packard's market-adjusted stock return of -68\% from 2000 to 2002. Another interesting example is Thomas Siebel of Siebel Systems, Inc., who drew 132 articles and 65 negative articles about compensation in 2003, and yet received no pay in 2002 . However, Mr. Siebel exercised a substantial dollar amount of options in 2002 (as well as in 2001), and also

\footnotetext{
${ }^{17}$ In Table 4, we do not winsorize any of the variables being shown.
} 
received a very large grant of new options in 2001. Siebel Systems also had extremely poor three-year market-adjusted stock price performance at $-123 \%$.

Table 5 (Panel B) lists the ten CEOs with the greatest percentage of negative articles in any given year during our sample period (i.e., the number of negative articles about compensation divided by the total number of articles about compensation). We restrict our attention to firms that have at least four articles on CEO compensation, because there are many CEOs with only one or two compensation-related articles, and where $100 \%$ of these articles are negative. The firms in Panel B are generally much smaller than those reported in Panel A which suggests that the total volume of press coverage is related to firm size. The results suggest a mixture of explanations for a high percentage of negative articles. The CEOs at Bear Stearns, EOG Resources, and Warnaco Group received very large total and residual compensation, and the CEO of Micron received a large stock option payout in the year of negative press coverage. The CEOs of Hillenbrand Industries, Nike, and Federal-Mogul received relatively modest levels of total compensation, and the negative press coverage seems to be due to their large negative market-adjusted returns. The explanations for Delphi Financial and Manpower are not clear, as both of these companies have low relative total compensation, no stock option payouts, and reasonable market-adjusted returns.

It is also useful to examine some features of negative publicity for CEOs selected on the basis of large excess compensation. For example, an examination of the ten CEOs in 2001 with the greatest excess total direct compensation indicates that eight out of the ten CEOs received some negative publicity in 2002 (not tabulated). Interestingly, some of these excessively paid CEOs received no media attention. Greg Reyes, CEO of Brocade Communications, received about $\$ 370$ million in total direct compensation, primarily due to a grant of more than 10 million 
stock options. However, even though he received the greatest amount of excess pay, Mr. Reyes received no negative publicity (although he was subsequently accused of stock option backdating). The reason for this lack of media attention is not obvious, particularly given the company's $-92 \%$ market-adjusted stock return performance over the prior three years. Similarly, Terry Semel of Yahoo! received \$273 million in total pay reflecting substantial excess pay, yet received no negative publicity.

\section{Results}

\subsection{Determinants of negative media attention about CEO compensation}

In this section, we explore the determinants of media attention about CEO compensation by estimating equations (1) and (2). Because there are multiple time-series observations per firm, the regression residuals are likely to exhibit autocorrelation. Similarly, since the data are aligned in calendar time, there is likely to be positive cross-sectional correlation in the residuals. In order to mitigate the econometric problems induced by this correlation structure, we compute Huber-White standard errors clustered by industry, following the method described by Rogers (1993) and Williams (2000). This clustering procedure assumes that cross-sectional correlation occurs within two-digit SIC code industries, but not across industries. These standard errors are robust to heteroscedasticity, cross-sectional dependence, and serial correlation in the residuals. The degrees of freedom used to evaluate the significance of the t-statistic are determined by the number of clusters (63 in our setting), rather than the number of observations. Industry and Year indicator variables are also included in all regressions but are not tabulated.

Of primary interest in equation (2) is whether Compensation in year $t$ affects the $\%$ of Negative Articles in year $\mathrm{t}+1$. A potential concern is that Compensation can be endogenous in 
this regression if negative publicity is perceived to be costly by boards and CEOs. ${ }^{18}$ Note that under the hypothesis that the press engages in sensationalism, negative press coverage is likely to be less costly than under the hypothesis that the press correctly identifies excessively paid CEOs. Further, even if the press can correctly identify firms with excess compensation, it is not clear that firms will perceive the costs of coverage to exceed the benefits of excess compensation. For these reasons, and because of the difficulty of identifying the required exogenous instrumental variables, we do not directly model the extent to which firms anticipate negative publicity about compensation. However, to shed light on whether firms perceive negative coverage to be costly, we examine changes in compensation following negative publicity in our tests of Hypotheses 4 and 6.

In Column (1) of Table 6, we find that media coverage of CEO compensation (ignoring the tone of the article) is focused on individuals and firms that are likely to attract the most reader attention. Specifically, we find a strong positive relation between total annual CEO compensation and press coverage. We also find that larger firms, firms in the S\&P 500, and firms with long-tenured CEOs receive more negative publicity. As might be expected, there is more coverage of CEO compensation when the firm is the subject of many general articles about the firm (perhaps due to familiarity with the company). The significant negative coefficients on NEGROA $\mathrm{t}$ and NEGROA $\mathrm{t}+1$ suggest that the press media writes articles about CEO compensation when there is negative operating performance. On the other hand, the marginally

\footnotetext{
${ }^{18}$ In this case, boards and CEOs will proactively reduce Compensation $n_{\text {it }}$ to avoid the costs. To the extent that this occurs, Compensation $_{\text {it }}$ will be lower when expected negative publicity at time $t+1$ is higher, and observed variation in excess pay across firms with high expected negative coverage will be smaller than if coverage was not costly. As a result, the press will write fewer negative articles than if firms ignored the possibility that they would receive negative press coverage. We expect that this reduction in excess pay, and resulting reduction in negative coverage would make it more difficult to document a relation between excess pay and press coverage.
} 
significant positive coefficient on NEGRET $_{t+1}$ suggests a lower probability of coverage when future returns become very negative.

In Column (2) of Table 6, we examine the relation between the percentage of negative articles and total annual CEO compensation. We observe that negative press coverage has a positive association with total CEO compensation. However, the other determinants of press coverage and negative coverage are quite different. For example, firm size and operating performance are not determinants of the percentage of negative compensation articles. The significant negative coefficient on POSRET $T_{t+1}$ and positive coefficient on NEGRET $_{t+1}$ indicate less negative coverage in the year after compensation when future returns are very high or low. The comparative results in Columns (1) and (2) indicate that the decision of the press to cover CEO compensation is quite different from the decision to write an article with a negative tone.

In Columns (3) and (4) of Table 6, we decompose Total Comp into its residual and expected components:

Total Comp $=$ Residual(Total Comp $)+$ Expected $($ Total Comp $)$.

The coefficients on both components are statistically significant, which suggests that press coverage is related to the total level of CEO compensation. However, negative press coverage is related only to Residual(Total Comp) and not to Expected(Total Comp). These results are consistent with Hypothesis 1 and inconsistent with Hypothesis 2, and suggest that the press makes at least some adjustments for a normal level of pay when deciding which CEOs to give negative attention.

A potential concern with interpreting the insignificant coefficient on Expected(Total Comp) in Column (4) is that many independent variables that determine expected compensation in equation (3) are similar to those that determine negative coverage in equation (2) (e.g., sales, 
S\&P 500 inclusion, and prior performance). Thus, even though Book-to-market ${ }_{\text {it- } 1}$ is unique to equation (3) and $\log (\text { Number of Firm Articles) })_{t+1}$ is unique to equation (2), it is conceivable that expected total compensation may be substantially explained by the control variables in equation (2), and thus become statistically insignificant in Column (4) of Table 6. As one way of mitigating this concern, in Column (5) we show that our inference in Column (4) is robust to removing the control variables.

A second potential concern with our results is that our industry and/or year controls could be obscuring our results. For example, our compensation models assume that the media adjust for pay differences across industry. To examine the robustness of our results to this concern, we conduct our analyses after dropping the industry and year indicators. These results (untabulated) yield the same inference.

In Columns (6) and (7) of Table 6, we show that our inference is robust to alternative approaches to modeling negative coverage. Column (6) shows the results of a probit model that predicts negative coverage, and Column (7) shows the results of a Poisson model for the number of negative articles. As in the Column (4) model for the proportion of negative coverage, and consistent with Hypothesis 1 and inconsistent with Hypothesis 2, the existence of negative press coverage and the volume of negative press coverage are only related to residual CEO compensation.

We recognize that our proxy for negative publicity measures true negative publicity with error. To explore the sensitivity of our results to this measurement error, we selected a random subsample of firm-years where we have manually classified compensation articles into negative and non-negative. To create this random sample, we began with the same random ordering used to test our negative search string and picked random CEOs that we had not examined previously. 
To limit our data collection costs, we added observations to this subsample until we could replicate the result in Column (4) in Table 6 that residual compensation better explains negative publicity than the raw compensation variable. This resulted in a random sample of 175 CEO-year observations. Two research assistants independently read all compensation-related articles for these CEO-years and manually coded them as negative or non-negative. In cases of disagreement between the research assistants, an author of this study read the article in question and chose the coding. Thus, for each of the 175 CEO-year observations, we have a "true" measure for negative publicity and the measure generated using our Perl script.

The results of this robustness analysis are presented in Table 7. In Column (1), we restate the results from Column (4) of Table 6 for comparison purposes. In Column (2), we present the results from estimating the same regression specification in Column (1), but using the subsample of 175 observations and the negative publicity measure generated via the Perl algorithm. The results for this subsample are very similar to those for the full sample in Column (1), although the t-statistics are somewhat lower relative to Column (1) because the sample is much smaller. In Column (3), we estimate the regression in Column (2) for the same subsample, but use the manually categorized measure of negative media attention. Although the magnitudes of the regression coefficients on the control variables vary relative to those in Column (2), the main inference on excess compensation is the same using the manually checked negative publicity measure as using the measure generated with the Perl algorithm. This sensitivity analysis suggests that our inference using the computer-coded negative publicity measure in the full sample is not induced by measurement error.

In Table 8 , we present results of additional regressions of $\%$ of negative compensation articles on additional measures of CEO compensation and payout. We conduct this multivariate 
analysis to test Hypothesis 3 and to provide additional evidence on Hypotheses 1 and 2. In the first column, we include Residual(Total Comp) and the same control variables as in Table 6 (control variables not tabulated). We exclude Expected(Total Comp) because we have already found it to be insignificant, and we want to focus attention on the additional variables. In the second column of Table 8, we include Total Payout (which includes the dollar amount collected by the CEO from exercising stock options instead of grant date option value) as an additional regressor. Total Payout has a significant positive relation with negative publicity. We observe a similar positive relation in Column (3) when we examine instead Residual(Total Payout). These results are consistent with the prediction in Hypothesis 3 that the press considers payouts from option exercises in addition to annual pay when deciding whether to give negative coverage to a CEO's compensation.

This finding that negative publicity is greater when a CEO realizes greater proceeds from option exercises suggests that negative coverage of CEO compensation does not derive solely from a demand for reliable information about corporate governance. Instead, the press appears to sensationalize the realization of payouts to CEOs from prior option grants. ${ }^{19}$ An alternative explanation to sensationalism is that large option exercises attract negative press coverage because large option exercises proxy for past overcompensation (i.e., excessive prior grants of equity-based compensation). To shed light on this possibility, we add two additional lags of excess Total Comp to the regression in Column 4. Although the requirement of lagged compensation data reduces the sample size by about $35 \%$ to 1,683 observations, Residual(Total Payout) remains significant. Thus, the relation between negative coverage and option exercises

\footnotetext{
${ }^{19}$ As an alternative, and perhaps more direct, way to examine Hypothesis 3, we compute the frequency with which stock option exercises are mentioned in negative press articles. Consistent with Hypothesis 3 that option exercises are associated with negative publicity, we find that option exercises are mentioned in about $25 \%$ of negative articles. By comparison, option grants are mentioned in a similar fraction of negative articles, also about $25 \%$.
} 
appears to be robust to controlling for a relation between option exercises and excess compensation.

In Column (5), we examine a percentage measure of excess total compensation, \%Residual(Total Comp), which we compute using equation (5). This specification addresses the question of whether the press is concerned only with dollar excess pay, or also with percentage excess pay. For example, is the press equally critical of two CEOs with excess pay of one million dollars, even though one CEO may work at a small firm and be overpaid by $100 \%$, whereas the other CEO works for a large firm and is overpaid by only $10 \%$ ? If the press focuses more on percentage residuals and $\log$ (pay) comparisons, as is common in the academic literature, we would expect that the percentage residual, and not the dollar residual, would be significant in the negative coverage model. However, the result in Column (5) shows that residual Total Comp is related to negative publicity, while percentage residual Total Comp is not statistically related to negative publicity.

The results in Tables 6 and 8 provide evidence that the financial press caters to multiple consumer demands for coverage of CEO compensation. We observe that the press is drawn to total CEO compensation, but that negative-toned publicity is related to residual total compensation. Thus, the press appears to make at least some adjustments for a normal level of pay when deciding which CEOs deserve negative attention. However, negative publicity is also related to CEOs' realized payouts from option exercises. This negative publicity following excess option exercises is unrelated to excess pay, and therefore, appears to be sensationalism. Large dollar receipts from option exercises generally imply that the CEO has performed very well by increasing the stock price over an extended period of time, and the portfolio rebalancing that occurs at the time of such option exercises can be optimal from the perspective of both the 
firm and the executive. Finally, our finding that the press appears to be concerned only about dollar excess pay and not percentage excess pay may also indicate a lack of sophistication (although our inference is limited by the fact that percentage excess pay has a fairly highly correlation of about 0.6 with dollar excess pay). The lack of an association between negative publicity and percentage excess pay suggests that the press is equally critical of two CEOs with excess pay of one million dollars, for example, even though one CEO may work at a small firm and be overpaid by $100 \%$, while the other CEO works for a large firm and is overpaid by only $10 \%$.

\subsection{Impact of negative publicity on future CEO compensation and turnover}

In Table 9, we test Hypotheses 4, 5, and 6 by analyzing whether firms or CEOs respond to negative media attention by making changes in pay, turnover decisions, and option payouts. We test for these changes by examining the association between negative publicity in year $\mathrm{t}+1$ and changes in percentage excess pay over the two-year period ending year $t+2$ (i.e., year $t+2$ percentage excess pay minus year $t$ percentage excess pay) and turnover in year $t+2$. For the turnover tests, we require that the firm's stock be traded all of year $t+1$, which restricts the sample to 10,431 observations. For the pay change tests, we require data on year $t+2$ pay, which lowers the sample to 8,791 observations.

By examining residual pay, we ensure that the pay changes represent changes in excess pay, not changes in firm characteristics. We examine percentage excess pay, and not dollar excess pay, under the assumption that boards are more concerned about excess pay when it becomes large relative to benchmarks. For example, if two CEOs have expected pay of one million and ten million dollars, and both have excess pay of one million dollars, we assume that the board is more likely to take action on the first CEO, who is overpaid by $100 \%$, than on the 
second CEO, who is overpaid by $10 \%$. To measure $\%$ Residual $\left(\right.$ Compensation $\left._{t}\right)$, we use equation (5). We measure the two-year change, Change in \%Residual(Compensation $)_{t+2}$, as $\left(\%\right.$ Residual $\left(\right.$ Compensation $\left._{\mathrm{t}+2}\right)-\% \operatorname{Residual}\left(\right.$ Compensation $\left.\left._{\mathrm{t}}\right)\right) .{ }^{20}$ Finally, because we wish to examine how negative publicity affects compensation and turnover for the full sample, we measure actual negative publicity unconditionally: Negative Publicity $=\%$ of Negative Articles $_{\mathrm{t}+1}$ if Coverage $=1$, and 0 otherwise. This variable considers no coverage to be no negative publicity.

In Column (1) of Table 9, we show that CEOs who receive more negative publicity have significantly lower two-year Changes in \%Residual(Total Comp) than CEOs with less unexpected negative publicity. These results are consistent with Johnson, Porter and Shackell (1997), who find that the existence of a negative tone article in one of five leading periodicals is associated with a smaller increase in total CEO pay. However, one problem with both our analysis in Column (1) and that of Johnson et al. (1997) is that there is strong mean reversion in pay (and unexpected pay) among the general population of CEOs. In particular, when a CEO has high pay in a given year, the pay in subsequent years will generally be lower, and this will produce a natural negative two-year change in pay. In addition, the results in Tables 6 and 8 indicate that highly paid CEOs are also more likely to receive negative media attention. Therefore, CEOs that draw negative media attention are more likely to experience mean reversion in pay, but this relation may not be causal. We control for mean reversion in Changes in \%Residual(Total Comp) in our regression by including lagged \%Residual(Total Comp). Column (2) shows the results from adding this control. We find strong confirmation of mean

\footnotetext{
${ }^{20}$ We obtain similar inference - that unexpected publicity does not lower pay - when we examine instead the dollar change in pay (not tabulated).
} 
reversion in CEO pay, but no evidence that press coverage affects CEO compensation, and therefore, no evidence supporting Hypothesis 4.

A second concern with this regression is that we show in Table 6 that negative publicity is determined by a variety of firm characteristics besides compensation, and our inference may be affected by failure to control for these characteristics. To address this concern, we estimate a measure of expected negative publicity using the coefficients obtained from estimating equations (1) and (2), but excluding Total Comp. ${ }^{21}$ We subtract this expected negative coverage measure from actual negative coverage to create unexpected negative coverage. Column (3) shows that the results from Column (2) are unaffected by adding this control.

In Table 9, Column (4), we examine CEO turnover in the year following negative publicity using the following logit model:

$$
\text { Turnover }_{\mathrm{t}+2}=\mathrm{b}_{0}+\mathrm{b}_{1} \text { Unexpected Negative Publicity }_{\mathrm{t}+1}+\text { controls }_{\mathrm{t}+1}+\mathrm{u}_{\mathrm{t}+1}
$$

Prior literature (e.g., Murphy, 1999) shows that turnover is higher for CEOs approaching retirement age and for CEOs with poor industry-adjusted performance. To control for these effects, we include an indicator variable equal to one when the CEO is 64 or older, stock return less industry median stock return ("Ind-Adj. RET"), and ROA less industry median ROA ("IndAdj. ROA"). ${ }^{22}$ We also include $\log ($ Sales $)$ to control for firm size effects. The coefficient on

\footnotetext{
${ }^{21}$ Specifically, we estimate equation (1) to obtain E[Prob(Coverage $\left.\left.\mathrm{t}_{t+1}\right)\right]$. We then estimate equation (2) for CEOs with coverage, and apply the estimated coefficients to the entire sample to compute a proxy for the expected level of negative press given coverage $\mathrm{E}\left[\%\right.$ of Negative Articles $\mathrm{t}_{\mathrm{t}+1} \mid$ Coverage $\left._{\mathrm{t}+1}\right]$. Finally we compute $\mathrm{E}[\%$ of Negative Articles $\left._{t+1}\right]=E\left[\text { Prob }\left(\text { Coverage }_{t+1}\right)\right]^{*} E\left[\%\right.$ of Negative Articles $s_{t+1} \mid$ Coverage $\left._{t+1}\right]$.

${ }^{22} \mathrm{We}$ hand-collect age data when this variable is missing from ЕхесuСomp.
} 
unexpected negative publicity is not statistically significant in Column (4), and not consistent with Hypothesis $5 .^{23}$

In Column (5) of Table 9, we test Hypothesis 6 that option exercises decline following negative media attention. To test this hypothesis, we use two-year changes in \%Residual(Total Payout) as the dependent variable. We find no evidence that CEOs receiving negative publicity have lower two-year changes in Total Payout, which provides no support for Hypothesis 6. As sensitivity analyses, we re-estimate the regression in Column (5) after replacing Total Payout (which includes cash pay and restricted stock) with dependent variables that measure changes in option exercises and changes in option exercises as a percentage of exercisable options (not tabulated). We obtain the same inference in these sensitivity analyses: Option exercises are not significantly lower for CEOs who have received negative publicity.

There are several potential explanations for the lack of support for Hypotheses 4 through 6 in Table 9. One possibility is that firms with large excess pay are poorly governed, and that poorly governed firms do not respond to external pressure (Del Guercio, Wallis and Woidtke, 2004). Alternatively, to the extent that the media sensationalizes articles about executive compensation, CEOs may be able to argue to their boards and shareholders that any negative coverage they receive is due to sensationalism and not excess pay, and that their pay practices are reasonable and do not require change. In other words, to the extent that the press generates many "false positive" claims about excess pay, its "true positive" claims can be discounted. Finally, if negative media attention imposes costs on firms, and firms that expect to be targeted are proactive in avoiding the cost associated with this type of publicity, it will be difficult to

\footnotetext{
${ }^{23}$ Our sample excludes approximately 400 observations where turnover appears to be due to acquisition or bankruptcy. If we include these observations, the results are qualitatively identical in the sense that negative publicity is statistically insignificant while the controls remain highly significant.
} 
detect changes in compensation policy (i.e., our tests will be conservative with respect to identifying the effects of negative media attention on firm's compensation policies).

\subsection{Sensitivity tests}

One concern with the construction of our press coverage variable is that we code releases of identical news articles by different sources as separate observations. To test the sensitivity of our results to this issue, we recode the press coverage variable to limit negative articles and all articles to one per firm per day. We do this as a way of limiting re-published news because it is not possible using computational methods to identify articles that follow a common source (subsequent news stories tend to expand or contract the information in the original source). When we recode the press variable so that it is not influenced by duplicate articles, $\%$ of Negative Articles $_{\mathrm{t}+1}$ increases slightly from $28.2 \%$ to $28.6 \%$ (because repeated non-negative coverage is slightly more common than repeated negative coverage). None of our inferences change when we use this modified variable.

A related concern with our press variable is that the media could write negative articles on compensation about issues that are not necessarily perceived as negative by shareholders. One example is that negative articles may be related to change of control arrangements. When the criticism is about a contract that includes a golden parachute or severance payment, this may not concern shareholders, since parachutes and severance agreements can be optimal components of compensation arrangements. Accordingly, we would not necessarily expect to see a reduction in CEO pay or an increase in turnover in the following year (especially if the story was about a prior CEO). To address this concern, we search the text of our articles and remove articles containing the words "golden parachute" or "severance." This elimination reduces \% of Negative Articles $_{\mathrm{t}+1}$ from $28 \%$ to $26 \%$, but does not affect our statistical inferences. 
A second example of potentially confounding press coverage is when the media is spurred by employees or unions to write negative articles about pay when there are layoffs or reorganizations. Again, these cases may not cause shareholders to be concerned about executive compensation. To address this concern, we search the text of our articles and remove articles containing the words "layoff" or "reorganization." This elimination reduces the \% of Negative Articles $_{t+1}$ from $28 \%$ to $26 \%$, but again does not affect our statistical inferences. It also does not

affect our inference if we remove articles about both "golden parachute" or "severance" and "layoff” or "reorganization."

\section{Summary and Conclusions}

Executive compensation continues to be an extremely controversial topic for boards of directors, institutional investors, governance activists, and governmental regulators. In this paper, we examine the role of the popular and business press as a monitor and potential change agent for the level and mix of executive pay. We examine two general research questions: What attributes cause the press to generate negative articles about CEO compensation? Does the negative press coverage cause firms to change their compensation policies?

Using a large sample of CEOs and an exhaustive set of press articles on compensation for these executives, we find that negative press coverage is associated with the level and source of compensation. However, the results are mixed with regard to the objectives of the press. In particular, we find some evidence that the press makes adjustments for standard economic determinants of compensation before producing a negative article, in that the press focuses on excess pay as opposed to raw pay levels. However, consistent with "sensationalism," we also find evidence that the press focuses negative attention on CEOs with large option exercises, 
which reflect payouts from accumulated multi-year compensation programs. Finally, we find no evidence that negative press coverage motivates firms to substantially change their compensation practices or turnover decisions. Thus, it is unclear whether the press has an effect on the compensation choices made by the board of directors.

Our analysis has a number of limitations that are typical of research into new areas. First, there is not a well-established objective function for the press, and this makes it difficult to appropriately design empirical tests. Second, although we have conducted a variety of validity tests, our indicators for negative press coverage have measurement error, and this may cause our coefficient estimates to be inconsistent. Third, we do not have a well-established model for the determinants of press coverage, and this raises concerns about our measure of excess, or unexpected, negative articles. Nevertheless, we provide some of the first evidence on the decision model of the press regarding the reporting on CEO compensation and on whether firms respond to this type of external criticism. 


\section{References}

Bebchuk, L., Fried, J., 2004. Pay without Performance: The unfulfilled promise of executive compensation. Cambridge, MA: Harvard University Press.

Core, J., Holthausen, R., Larcker, D., 1999. Corporate governance, chief executive officer compensation, and firm performance. Journal of Financial Economics 51, 371-406.

Del Guercio, D., Wallis, L., Woidtke, T., 2004. Do board members pay attention when institutional investors 'just vote no'? CEO and director turnover associated with shareholder activism. University of Oregon. Unpublished working paper.

Dial, J., Murphy, K., 1995. Incentives, downsizing, and value creation at General Dynamics. Journal of Financial Economics 37, 261-314.

Dyck, A., Zingales, L., 2002. The corporate governance role of the media. Harvard University. Unpublished working paper.

Dyck, A., Zingales, L., 2004. Private benefits of control: an international comparison. Journal of Finance 59, 537-600.

Fama, E., Jensen, M., 1983. Separation of ownership and control. Journal of Law and Economics $26,301-325$.

Francis, J., Huang, A., Rajgopal, S., Zang, A., 2004. CEO reputation and earnings quality. University of Washington. Unpublished working paper.

Hall, B., Murphy, K.J., 2002. Stock options for undiversified executives. Journal of Accounting and Economics 33, 3-42.

Heckman, J., 1979. Sample selection bias as a specification error. Econometrica 47, 153-61.

Heron, R., Lie, E., 2007. Does backdating explain the stock price pattern around executive stock option grants? Journal of Financial Economics 83, 271-295.

Holmstrom, B., Kaplan, S., 2003. The state of U.S. corporate governance: what's right and what's wrong? University of Chicago. Unpublished working paper.

Jensen, M., 1979. Toward a theory of the press. In: Brunner, K. (Ed.), Economics and Social Institutions. Martinus Nijhoff Publishing Company.

Johnson, M., Porter, S., Shackell, M., 1997. Stakeholder pressure and the structure of executive compensation. University of Notre Dame. Unpublished working paper.

Louis, H., Joe, J., Robinson, D., 2004. Managers' and investors' responses to media exposure of board ineffectiveness. Pennsylvania State University. Unpublished working paper. 
Miller, G., 2006. The press as a watchdog for accounting fraud. Journal of Accounting Research $44,1001-1033$.

Murphy, K., 1999. Executive compensation. In: Ashenfelter, O., Card, D. (Eds.), Handbook of Labor Economics 3, 2485-2563. Amsterdam, Netherlands: Elsevier.

Papke, L. E., Wooldridge, J., 1996. Econometric methods for fractional response variables with an application to 401(k) plan participation rates. Journal of Applied Econometrics 11, 619-632.

Rogers, W., 1993. Regression standard errors in clustered samples. Stata Technical Bulletin 13, 19-23. Reprinted in Stata Technical Bulletin Reprints 3, 88-94.

Smith, C., Watts, R., 1992. The investment opportunity set and corporate financing, dividends, and compensation policies. Journal of Financial Economics 32, 263-292.

Williams, R., 2000. A note on robust variance estimation for cluster-correlated data. Biometrica $56,645-646$.

Zingales, L., 2000. In search of new foundations. Journal of Finance 55, 1623-1653. 


\section{Appendix A}

\section{PERL search string used to code articles as negative-toned}

(CEO name or CEO name's or executive* or CEO*) near25

(high* near7 (salar* or bonus* or pay* or paid or compensat* or benefit*)

or excess* near7 (salar* or bonus* or pay* or paid or compensat* or benefit* or option*) or lofty near7 (salar* or bonus* or pay* or paid or compensat* or benefit* or option*) or hefty near7 (salar* or bonus* or pay* or paid or compensat* or benefit* or option*) or large adj7 (salar* or bonus* or pay* or paid or compensat* or benefit* or option*) or rich near7 (salar* or bonus* or pay* or paid or compensat* or benefit* or option*) or big* near7 (salar* or bonus* or pay* or paid or compensat* or benefit* or option*) or outsize* near7 (salar* or bonus* or pay* or paid or compensat* or benefit* or option*) or huge near7 (salar* or bonus* or pay* or paid or compensat* or benefit* or option*) or generous near7 (salar* or bonus* or pay* or paid or compensat* or benefit* or option*) or exorbitant* near7 (salar* or bonus* or pay* or paid or compensat* or benefit* or option*) or fat* near7 (salar* or bonus* or pay* or paid or compensat* or benefit* or option*) or gargantuan near7 (salar* or bonus* or pay* or paid or compensat* or benefit* or option*) or bonanza* near7 (salar* or bonus* or pay* or paid or compensat* or benefit* or option*) or jumbo near7 (salar* or bonus* or pay* or paid or compensat* or benefit* or option*) or whopp* near7 (salar* or bonus* or pay* or paid or compensat* or benefit* or option*) or astound* near7 (salar* or bonus* or pay* or paid or compensat* or benefit* or option*) or ridiculous* near7 (salar* or bonus* or pay* or paid or compensat* or benefit* or option*) or stagger* near7 (salar* or bonus* or pay* or paid or compensat* or benefit* or option*) or handsome* near7 (salar* or bonus* or pay* or paid or compensat* or benefit* or option*) or lucrative near7 (pay* or compensat* or option*)

or critic* near7 (pay* or compensat*)

or best near7 paid

or reap* adj7 million*

or self-serving

or largesse

or overpaid

or lavish

or perks

or perquisites

or windfall*

or earn* more than

or was paid more than

or receiv* more than

or made more than) 


\title{
Appendix B
}

\section{Excerpts from two articles for E*Trade Financial Corp., CEO Christos Cotsakos}

\author{
Article 1: $\quad$ Tone $=$ Non-Negative \\ Title: $\quad$ Technology Briefing Executive Pay: $\$ 77$ Million For E*Trade Chief \\ Date: $\quad 1$ May 2002 \\ Source: $\quad$ The New York Times
}

The E*Trade Group, the online brokerage firm, paid its chief executive, Christos M. Cotsakos, left, $\$ 77$ million in 2001. The compensation included \$29 million in restricted stock, a forgiven $\$ 15$ million loan and $\$ 15$ million for taxes after the loan was reclassified as compensation, according to a Securities and Exchange Commission filing. E*Trade had a $\$ 241$ million loss in 2001. Mr. Cotsakos received $\$ 797,880$ in salary and a bonus of $\$ 4.1$ million, compared with $\$ 756,346$ in salary and a $\$ 1.4$ million bonus in 2000 . The company paid $\$ 2.4$ million in taxes on stock that vested, and $\$ 279,678$ in taxes on retirement contributions. He also gained $\$ 11$ million by exercising stock options.

\section{Article 2: $\quad$ Tone $=$ Negative}

Title: $\quad$ No Discount: $E^{*}$ Trade CEO Gets Pay Deal Of $\$ 80$ Million

Date: $\quad 1$ May 2002

Source: $\quad$ The Wall Street Journal

Christos Cotsakos, chairman and chief executive of the discount-brokerage firm, appears to have been the highest-paid CEO on Wall Street in 2001.

The outsize package included $\$ 797,880$ in salary, a bonus of $\$ 4.1$ million, a forgiven loan of $\$ 15$ million, an additional $\$ 15$ million in company-paid taxes on the loan, which was reclassified as compensation, and $\$ 9.9$ million of "other compensation" in contributions to his retirement plan. The total also includes stock options valued at \$5.9 million and restricted stock valued at \$29 million. He also pocketed $\$ 11$ million in proceeds from exercising stock options granted in previous years. 


\section{Table 1}

Trends in CEO Compensation and Compensation-Related Press Coverage

The data consist of ExecuComp CEOs from fiscal years 1993 to 2001. The articles on CEO compensation are obtained from the Factiva database for the year after pay was earned, that is years 1994 to 2002 . N is the sample size for that year. Total Comp $\mathrm{t}_{\mathrm{t}}$ is the sample median salary, bonus, long-term incentive plan payouts, the value of restricted stock grants, the value of options granted during the year, and any other annual pay (in \$000s) in the fiscal year shown. Sales $t_{\text {- } 1}$ is the sample median firm sales for year t-1. Number of Articles per CEO is the sample average total number of articles written about the CEO's compensation in the Factiva database in the fiscal year $\mathrm{t}+1$ after pay was earned. Percentage of CEOs with Coverage $t_{t+1}$ is the percentage of CEOs for whom the press covers CEO compensation. Fraction of CEO compensation articles with negative tone $\mathrm{t}_{+1}$ is the total number of negative articles written about the CEOs' compensation (using the algorithm described in the text to measure negative tone) as a percentage of the total number of articles written about the CEOs' compensation.

\begin{tabular}{|c|c|c|c|c|c|c|}
\hline Year & $\mathbf{N}$ & $\begin{array}{c}\text { Total } \\
\text { Compt } \\
\text { (Thousands) }\end{array}$ & $\begin{array}{c}\text { Sales }_{\mathrm{t}-1} \\
\text { (millions) }\end{array}$ & $\begin{array}{c}\text { Number } \\
\text { of } \\
\text { Articles } \\
\text { per } \\
\text { CEO }_{t+1} \\
\end{array}$ & $\begin{array}{c}\text { Percentage } \\
\text { of CEOs } \\
\text { with } \\
\text { Coverage }_{t+1}\end{array}$ & $\begin{array}{c}\text { Fraction of } \\
\text { CEO } \\
\text { compensation } \\
\text { articles with } \\
\text { negative } \\
\text { tone }_{t+1} \\
\end{array}$ \\
\hline 1993 & 1,203 & 1,176 & 883 & 0.27 & 0.09 & $43 \%$ \\
\hline 1994 & 1,250 & 1,345 & 859 & 0.35 & 0.12 & $32 \%$ \\
\hline 1995 & 1,305 & 1,378 & 872 & 0.47 & 0.13 & $37 \%$ \\
\hline 1996 & 1,316 & 1,605 & 950 & 0.85 & 0.21 & $31 \%$ \\
\hline 1997 & 1,327 & 1,859 & 959 & 1.01 & 0.22 & $34 \%$ \\
\hline 1998 & 1,392 & 1,972 & 936 & 1.05 & 0.24 & $32 \%$ \\
\hline 1999 & 1,389 & 2,248 & 1,058 & 0.98 & 0.23 & $30 \%$ \\
\hline 2000 & 1,443 & 2,578 & 1,061 & 1.12 & 0.26 & $28 \%$ \\
\hline 2001 & 1,465 & 2,632 & 1,162 & 2.23 & 0.38 & $31 \%$ \\
\hline \multicolumn{2}{|c|}{$\begin{array}{l}\text { Percentage Change } \\
\text { from } 1993 \text { to } 2001\end{array}$} & $124 \%$ & $32 \%$ & $724 \%$ & $302 \%$ & $-28 \%$ \\
\hline
\end{tabular}


Table 2

Annual Data on the Source of Articles on CEO Compensation

The sample consists of ExecuComp CEOs from fiscal years 1993 to 2001. The articles on CEO compensation are obtained from the Factiva database for years 1994 to 2002, including the source of each article. Number of articles - all topics is the total number of articles for all sample firms for each year. Number of sources - CEO compensation articles is the total number of different publications that printed an article about CEO compensation for each year. Number of CEO compensation articles is the total number of articles about CEO compensation for all sample firms for each year. Fraction of CEO compensation articles with negative tone $t_{t+1}$ is the total number of negative articles written about the CEOs' compensation (using the algorithm described in the text to measure negative tone) as a percentage of the total number of articles written about the CEOs' compensation. Number of WSJ articles is the total number of The Wall Street Journal (WSJ) articles on CEO compensation for our sample, and fraction of compensation articles with negative tone ${ }_{t+1}$ is the percentage of WSJ articles with negative tone (using the algorithm described in the text to measure negative tone). Number of negative tone WSJ articles is the number of articles where negative tone is assessed using the algorithm described in the text.

Panel A. Trends in Articles about CEO Compensation and Their Sources

\begin{tabular}{|c|c|c|c|c|c|c|}
\hline Year & $\begin{array}{c}\text { Number } \\
\text { of articles } \\
\text { - all } \\
\text { topics } \\
\end{array}$ & $\begin{array}{c}\text { Number of } \\
\text { sources - } \\
\text { CEO } \\
\text { compensation } \\
\text { articles } \\
\end{array}$ & $\begin{array}{c}\text { Number of } \\
\text { CEO } \\
\text { compensation } \\
\text { articles } \\
\end{array}$ & $\begin{array}{c}\text { Fraction of } \\
\text { CEO } \\
\text { compensation } \\
\text { articles with } \\
\text { negative tone }\end{array}$ & $\begin{array}{l}\text { Number } \\
\text { of WSJ } \\
\text { articles }\end{array}$ & $\begin{array}{c}\text { Fraction } \\
\text { of WSJ } \\
\text { articles } \\
\text { with } \\
\text { negative } \\
\text { tone } \\
\end{array}$ \\
\hline & (1) & $(2)$ & (3) & (4) & (5) & (6) \\
\hline 1994 & 216,677 & 62 & 325 & $43 \%$ & 58 & $48 \%$ \\
\hline 1995 & 196,032 & 97 & 439 & $32 \%$ & 74 & $45 \%$ \\
\hline 1996 & 178,378 & 131 & 609 & $37 \%$ & 112 & $43 \%$ \\
\hline 1997 & 233,665 & 234 & 1117 & $31 \%$ & 104 & $38 \%$ \\
\hline 1998 & 303,850 & 244 & 1,346 & $34 \%$ & 122 & $39 \%$ \\
\hline 1999 & 543,058 & 279 & 1,465 & $32 \%$ & 149 & $38 \%$ \\
\hline 2000 & 514,747 & 308 & 1,362 & $30 \%$ & 44 & $25 \%$ \\
\hline 2001 & 542,096 & 323 & 1,616 & $28 \%$ & 81 & $25 \%$ \\
\hline 2002 & 825,887 & 470 & 3,263 & $31 \%$ & 210 & $40 \%$ \\
\hline $\begin{array}{c}\text { Percentage } \\
\text { Change }\end{array}$ & $281 \%$ & $658 \%$ & $904 \%$ & $-28 \%$ & $262 \%$ & $-17 \%$ \\
\hline
\end{tabular}


Table 2 (continued)

Panel B. Major Sources and Tone of Coverage

\begin{tabular}{|c|c|c|c|c|}
\hline Type of Source & Source & $\begin{array}{c}\text { Number of CEO } \\
\text { compensation } \\
\text { articles }\end{array}$ & $\begin{array}{c}\text { Number of } \\
\text { negative tone } \\
\text { CEO } \\
\text { compensation } \\
\text { articles } \\
\end{array}$ & $\begin{array}{c}\text { Fraction of } \\
\text { CEO } \\
\text { compensation } \\
\text { articles with } \\
\text { negative tone }\end{array}$ \\
\hline \multirow[t]{4}{*}{ Newswire } & AP & 235 & 75 & $32 \%$ \\
\hline & Dow Jones & 717 & 137 & $19 \%$ \\
\hline & Reuters & 1,271 & 279 & $22 \%$ \\
\hline & Sub-Total & 2,223 & 491 & $22 \%$ \\
\hline \multirow{11}{*}{ Newspaper } & $\begin{array}{c}\text { Chicago Sun- } \\
\text { Times }\end{array}$ & 110 & 29 & $26 \%$ \\
\hline & Financial Times & 252 & 99 & $39 \%$ \\
\hline & New York Times & 260 & 88 & $34 \%$ \\
\hline & The Globe And & & & \\
\hline & Mail & 190 & 49 & $26 \%$ \\
\hline & The Washington & & & \\
\hline & Post & 123 & 49 & $40 \%$ \\
\hline & USA Today & 49 & 22 & $45 \%$ \\
\hline & Wall Street & & & \\
\hline & Journal & 954 & 367 & $38 \%$ \\
\hline & Sub-Total & 1,938 & 703 & $36 \%$ \\
\hline \multirow[t]{5}{*}{ Magazine } & Barron's & 44 & 27 & $61 \%$ \\
\hline & Business Week & 43 & 21 & $49 \%$ \\
\hline & Forbes & 43 & 15 & $35 \%$ \\
\hline & Fortune & 40 & 17 & $43 \%$ \\
\hline & Sub-Total & 170 & 80 & $47 \%$ \\
\hline
\end{tabular}




\section{Table 3}

\section{Descriptive Statistics}

This table presents descriptive statistics for the variables used in the subsequent analyses. The sample consists of 12,090 observations for ExecuComp CEOs from fiscal years 1993 to 2001. The articles on CEO compensation are obtained from the Factiva database for years 1994 to 2002. Number of Articles $t_{t+1}$ is the total number of articles written about the CEO's compensation. Coverage $e_{t+1}$ is an indicator variable for whether the press covers CEO compensation. Number of Negative Articles $\mathrm{t}_{t+1}$ is the total number of negative tone articles written about the CEO's compensation, where negative tone is assessed using the algorithm described in the text. \% of Negative Articles $\mathrm{t}_{\mathrm{t}+1}$ is Number of Negative Articles ${ }_{t+1}$ divided by Number of Articles $_{t+1}$. This variable is tabulated only for the 2,607 observations with Coverage $_{t+1}$ greater than zero. Number of Firm Articles ${ }_{t+1}$ is the number of articles (all topics) written about the firm during year $t+1$. Total Comp is salary, bonus, long-term incentive plan payouts, the value of restricted stock grants, the value of options granted during the year, and any other annual pay for the CEO in year $t$. Total Payout $t_{t}$ is salary, bonus, long-term incentive plan payouts, the value of restricted stock grants, the proceeds from options exercised during the year, and any other annual pay for the CEO in year $t$. Tenure $t_{t}$ is the CEO's tenure in years at the end of year t. S\&P500 is one if the firm is in the S\&P500 at the end of year t, and zero otherwise. Sales $_{\mathrm{t}-1}$ (in millions of dollars) is firm sales for year $\mathrm{t}-1$. Bk/ $\mathrm{Mkt}_{\mathrm{t}-1}$ is (book value of assets) / (book value of liabilities + market value of equity) at the end of year $t-1 . R T_{t}$ is the firm's return for the year $t$. ROA $t$ is income before extraordinary items divided by average total assets for the year $t$.

\begin{tabular}{|c|c|c|c|c|c|c|c|c|}
\hline Variable & Mean & Std Dev & $\mathbf{P 1}$ & Q1 & Median & Q3 & P90 & P99 \\
\hline Number of Articles $t_{t+1}$ & 0.81 & 2.79 & 0.00 & 0.00 & 0.00 & 0.00 & 2.00 & 16.00 \\
\hline Coverage $_{t+1}$ & 0.22 & 0.41 & 0.00 & 0.00 & 0.00 & 0.00 & 1.00 & 1.00 \\
\hline Number of Negative Articles ${ }_{t+1}$ & 0.23 & 0.92 & 0.00 & 0.00 & 0.00 & 0.00 & 1.00 & 5.00 \\
\hline$\%$ of Negative Articles $\mathrm{t}_{\mathrm{t}+1}$ & 0.28 & 0.37 & 0.00 & 0.00 & 0.00 & 0.50 & 1.00 & 1.00 \\
\hline Number of Firm Articles ${ }_{t+1}$ & 293.85 & 669.29 & 1.00 & 52.00 & 116.00 & 244.00 & 599.00 & $3,856.00$ \\
\hline Total Comp $\mathrm{t}_{\mathrm{t}}$ & 3,746 & 6,237 & 189 & 904 & 1,758 & 3,822 & 8,334 & 32,909 \\
\hline Total Payout $_{\mathrm{t}}$ & 3,122 & 6,587 & 117 & 659 & 1,246 & 2,736 & 6,675 & 37,109 \\
\hline Tenure $_{t}$ & 7.60 & 7.45 & 0.08 & 2.17 & 5.33 & 10.58 & 16.92 & 35.92 \\
\hline $\mathrm{SP} 500_{\mathrm{t}}$ & 0.33 & 0.47 & 0.00 & 0.00 & 0.00 & 1.00 & 1.00 & 1.00 \\
\hline Sales $_{\mathrm{t}-1}$ & 3,280 & 6,296 & 17 & 353 & 980 & 2,989 & 8,775 & 34,654 \\
\hline $\mathrm{Bk} / \mathrm{Mkt}_{\mathrm{t}-1}$ & 0.65 & 0.27 & 0.11 & 0.44 & 0.66 & 0.86 & 0.98 & 1.20 \\
\hline $\mathrm{RET}_{\mathrm{t}}$ & 0.20 & 0.61 & -0.75 & -0.13 & 0.11 & 0.38 & 0.76 & 2.34 \\
\hline $\mathrm{ROA}_{\mathrm{t}}$ & 0.04 & 0.10 & -0.37 & 0.01 & 0.05 & 0.09 & 0.14 & 0.25 \\
\hline
\end{tabular}




\section{Table 4 \\ Regressions for Compensation Variables}

This table presents results of pooled cross-sectional OLS regressions for the logarithms of two measures of CEO compensation and the economic determinants of compensation. The sample consists of 12,090 observations for ExecuComp CEOs from fiscal years 1993 to 2001. Total Comp $\mathrm{t}_{\mathrm{t}}$ is salary, bonus, long-term incentive plan payouts, the value of restricted stock grants, the value of options granted during the year, and any other annual pay for the CEO in year t. Total Payout $t_{t}$ is salary, bonus, long-term incentive plan payouts, the value of restricted stock grants, the proceeds from options exercised during the year, and any other annual pay for the CEO in year $t . \log (\text { Tenure })_{t}$ is the logarithm of the CEO's tenure in years at the end of year t. S\&P500 is one if the firm is in the S\&P500 at the end of year $t$, and zero otherwise. $\log (\text { Sales })_{t-1}$ is the logarithm of firm sales for year $\mathrm{t}-1$. Bk/ $\mathrm{Mkt}_{\mathrm{t}-1}$ is (book value of assets) / (book value of liabilities + market value of equity) at the end of year $\mathrm{t}-1$. $\mathrm{RET}_{\mathrm{t}}$ is the firm's return for year $\mathrm{t}$. $\mathrm{RET}_{\mathrm{t}-1}$ is the firm's return for year $\mathrm{t}-1 . \mathrm{ROA}_{\mathrm{t}}$ is income before extraordinary items divided by average total assets for year t. $\mathrm{ROA}_{\mathrm{t}-1}$ is income before extraordinary items divided by average total assets for year $\mathrm{t}-1$. Fixed effects for year and 2-digit SIC codes are included in the regressions, but not tabulated. T-statistics using Huber-White robust standard errors are presented in parentheses below coefficient estimates. ${ }^{*}, *$, and $* * *$ indicate two-tailed statistical significance at 10,5 , and 1 percent levels, respectively.

\begin{tabular}{|c|c|c|}
\hline \multirow[b]{2}{*}{$\begin{array}{c}\text { Independent } \\
\text { Variable }\end{array}$} & \multicolumn{2}{|c|}{ Dependent Variable: } \\
\hline & $\log \left(\right.$ Total Comp $\left.\mathrm{C}_{\mathrm{t}}\right)$ & $\log \left(\right.$ Total Payout $\left.{ }_{t}\right)$ \\
\hline $\log (\text { Tenure })_{t}$ & $\begin{array}{c}-0.02 \\
(-0.80)\end{array}$ & $\begin{array}{c}0.13 * * * \\
(6.93)\end{array}$ \\
\hline $\log (\text { Sales })_{\mathrm{t}-1}$ & $\begin{array}{c}0.42 * * * \\
(17.96)\end{array}$ & $\begin{array}{c}0.40 * * * \\
(18.74)\end{array}$ \\
\hline $\mathrm{S} \& \mathrm{P} 500_{\mathrm{t}}$ & $\begin{array}{l}0.12 * * \\
(2.30)\end{array}$ & $\begin{array}{c}0.14 * * \\
(2.83)\end{array}$ \\
\hline $\mathrm{Bk} / \mathrm{Mkt}_{\mathrm{t}-1}$ & $\begin{array}{c}-0.99 * * * \\
(-9.76)\end{array}$ & $\begin{array}{c}-0.69 * * * \\
(-6.80)\end{array}$ \\
\hline $\mathrm{RET}_{\mathrm{t}}$ & $\begin{array}{c}0.27 * * * \\
(12.84)\end{array}$ & $\begin{array}{c}0.31 * * * \\
(11.64)\end{array}$ \\
\hline $\mathrm{RET}_{\mathrm{t}-1}$ & $\begin{array}{c}0.16 * * * \\
(6.71)\end{array}$ & $\begin{array}{c}0.26 * * * \\
(19.23)\end{array}$ \\
\hline $\mathrm{ROA}_{\mathrm{t}}$ & $\begin{array}{c}-1.00 * * * \\
(-5.87)\end{array}$ & $\begin{array}{l}0.40^{*} \\
(1.98)\end{array}$ \\
\hline $\mathrm{ROA}_{\mathrm{t}-1}$ & $\begin{array}{c}-0.45 * * \\
(-2.07)\end{array}$ & $\begin{array}{l}-0.51 * \\
(-1.72)\end{array}$ \\
\hline $\mathrm{R}^{2}$ & 0.4290 & 0.4274 \\
\hline
\end{tabular}


Table 5

Panel A. CEOs with Greatest Number of Articles

This table lists the CEOs with the greatest number of negative articles about their compensation from a sample consisting of 12,090 observations for ExecuComp CEOs from fiscal years 1993 to 2001. The articles on CEO compensation are obtained from the Factiva database for years 1994 to 2002 . Number of Articles ${ }_{t+1}$ is the total number of articles written about the CEO's compensation. \% of Negative Articles ${ }_{t+1}$ is the total number of negative tone articles written about the CEO's compensation where the negative tone is assessed using the algorithm described above in the text, divided by Number of Articles $\mathrm{t}_{\mathrm{t}+1}$. Tenure as CEO is the CEO's tenure in years at the end of the year. Total Comp is the sum of salary, bonus, long-term incentive plan payouts, the value of restricted stock grants, the value of options granted during the year, and any other annual pay for the CEO. Residual(Total Comp) is residual Total Comp computed using equation (5) and based on the linear regression model shown in Table 4. Total Payout is salary, bonus, long-term incentive plan payouts, the value of restricted stock grants, the proceeds from options exercised during the year, and any other annual pay for the CEO in year t. All compensation variables are in \$000s. Three-year Mkt-adj Stock Return is computed as the three-year compounded stock return through year $t+1$ minus the average sample three-year compounded stock return. Market Value of Equity is the market value of equity in millions of dollars at the end of year $\mathrm{t}-1$.

\begin{tabular}{|c|c|c|c|c|c|c|c|c|c|c|}
\hline $\begin{array}{c}\text { Company } \\
\text { Name } \\
\end{array}$ & $\begin{array}{c}\text { CEO } \\
\text { Last } \\
\text { Name } \\
\end{array}$ & Year & $\begin{array}{c}\text { Number of } \\
\text { Articles }_{t+1}\end{array}$ & $\begin{array}{c}\% \text { of } \\
\text { Negative } \\
\text { Articles }_{t+1}\end{array}$ & $\begin{array}{c}\text { Tenure } \\
\text { as } \\
\text { CEO } \\
\text { (years)t }\end{array}$ & $\begin{array}{c}\text { Total } \\
\text { Compt }_{t}\end{array}$ & $\begin{array}{c}\text { Residual } \\
\text { (Total } \\
\text { Comp)t }\end{array}$ & $\begin{array}{c}\text { Total } \\
\text { Payout }_{\mathrm{t}}\end{array}$ & $\begin{array}{c}\text { Three- } \\
\text { year } \\
\text { Mkt- } \\
\text { adj } \\
\text { Stock } \\
\text { Return }_{\text {t }}\end{array}$ & $\begin{array}{l}\text { Market } \\
\text { Value } \\
\text { of } \\
\text { Equity } \\
\text { (\$mil) } t\end{array}$ \\
\hline Tyco International & Kozlowski & 2001 & 320 & $57 \%$ & 9.2 & 77,767 & 55,390 & 42,177 & $-85 \%$ & 88,064 \\
\hline AMR Corp. & Carty & 2002 & 250 & $54 \%$ & 4.6 & 10,171 & 2,484 & 1,109 & $-111 \%$ & 1,030 \\
\hline Hewlett-Packard Co. & Fiorina & 2001 & 168 & $32 \%$ & 2.3 & 18,121 & $-11,533$ & 1,248 & $-68 \%$ & 32,633 \\
\hline Siebel Systems & Siebel & 2002 & 132 & $49 \%$ & 9.4 & 0 & $-6,994$ & 34,586 & $-123 \%$ & 3,600 \\
\hline Delta Air Lines & Mullin & 2002 & 121 & $73 \%$ & 5.3 & 14,039 & 6,901 & 4,870 & $-120 \%$ & 1,493 \\
\hline Qwest Commun. & Nacchio & 2001 & 116 & $35 \%$ & 4.9 & 74,115 & 57,349 & 101,995 & $-106 \%$ & 23,506 \\
\hline Disney (Walt) Co & Eisner & 1996 & 109 & $50 \%$ & 12.0 & 202,185 & 192,527 & 8,654 & $-7 \%$ & 42,631 \\
\hline
\end{tabular}




\section{Table 5 (continued) \\ Panel B. CEOs with Greatest Percentage of Negative Articles}

This table lists the CEOs with the greatest percentage of negative articles about their compensation from a sample consisting of 12,090 observations for ExecuComp CEOs from fiscal years 1993 to 2001. The articles on CEO compensation are obtained from the Factiva database for years 1994 to 2002 . Number of Articles $_{t+1}$ is the total number of articles written about the CEO's compensation. \% of Negative Articles $\mathrm{t}_{+1}$ is the total number of negative tone articles written about the CEO's compensation where the negative tone is assessed using the algorithm described above in the text, divided by Number of Articles ${ }_{t+1}$. Tenure as CEO is the CEO's tenure in years at the end of the year. Total Comp is salary, bonus, long-term incentive plan payouts, the value of restricted stock grants, the value of options granted during the year, and any other annual pay for the CEO. Residual(Total Comp) is residual Total Comp computed using equation (5) and based on the linear regression model shown in Table. Total Payout $t_{t}$ is salary, bonus, long-term incentive plan payouts, the value of restricted stock grants, the proceeds from options exercised during the year, and any other annual pay for the CEO in year t. All compensation variables are in \$000s. Three-year Mkt-adj Stock Return is computed as the three-year compounded stock return through year $\mathrm{t}+1$ minus the average sample three-year compounded stock return. Market Value of Equity is the market value of equity in millions of dollars at the end of year t-1

\begin{tabular}{|c|c|c|c|c|c|c|c|c|c|c|}
\hline $\begin{array}{c}\text { Company } \\
\text { Name }\end{array}$ & $\begin{array}{c}\text { CEO } \\
\text { Last } \\
\text { Name }\end{array}$ & Year & $\begin{array}{c}\text { Number } \\
\text { of } \\
\text { Articles }_{t+1}\end{array}$ & $\begin{array}{c}\text { \% of } \\
\text { Negative } \\
\text { Articles }_{t+1}\end{array}$ & $\begin{array}{c}\text { Tenure } \\
\text { as CEO } \\
\text { (years)t }\end{array}$ & $\begin{array}{c}\text { Total } \\
\text { Compt }\end{array}$ & $\begin{array}{c}\text { Residual( } \\
\text { Total } \\
\text { Comp)t }\end{array}$ & $\begin{array}{c}\text { Total } \\
\text { Payout }_{t}\end{array}$ & $\begin{array}{c}\text { Three- } \\
\text { year } \\
\text { Mkt- } \\
\text { adj } \\
\text { Stock } \\
\text { Return }\end{array}$ & $\begin{array}{c}\text { Marke } \\
\text { t Value } \\
\text { of } \\
\text { Equity } \\
\text { (\$mil)t }\end{array}$ \\
\hline Hillenbrand & Hillenbrand & 1998 & 12 & $100 \%$ & 9.6 & 3,887 & -51 & 2,936 & $-102 \%$ & 3,793 \\
\hline Nike Inc. & Knight & 1997 & 10 & $100 \%$ & 29.3 & 1,679 & $-4,256$ & 1,679 & $-56 \%$ & 13,202 \\
\hline Delphi & Rosenkranz & 2002 & 9 & $100 \%$ & 15.6 & 1,500 & $-1,327$ & 1,500 & $-1 \%$ & 783 \\
\hline Bear Stearns & Cayne & 1995 & 7 & $100 \%$ & 1.9 & 8,472 & 4,649 & 9,384 & $-26 \%$ & 2,508 \\
\hline Federal-Mogul & Miller & 2000 & 6 & $100 \%$ & 0.3 & 880 & $-1,960$ & 426 & $-149 \%$ & 163 \\
\hline Micron & Appleton & 1996 & 5 & $100 \%$ & 1.9 & 4,251 & 1,074 & 4,847 & $4 \%$ & 4,750 \\
\hline Bear Stearns & Cayne & 1998 & 5 & $100 \%$ & 4.9 & 27,176 & 16,260 & 27,176 & $28 \%$ & 6,663 \\
\hline $\mathrm{EOG}$ & Hoglund & 1994 & 4 & $100 \%$ & 7.3 & 13,365 & 11,477 & 20,114 & $4 \%$ & 3,000 \\
\hline Manpower Inc. & Fromstein & 1995 & 4 & $100 \%$ & 6.9 & 3,726 & -559 & 3,726 & $28 \%$ & 2,282 \\
\hline Warnaco & Wachner & 1996 & 4 & $100 \%$ & 9.3 & 20,490 & 17,301 & 9,434 & $-32 \%$ & 1,536 \\
\hline
\end{tabular}




\section{Table 6 \\ Estimates of the Determinants of Coverage and Negative Publicity Ratio}

The sample consists of 12,090 observations for ЕхесиComp CEOs from fiscal years 1993 to 2001. The articles on CEO compensation are obtained from the Factiva database for years 1994 to 2002 . The first and third (second, fourth, and fifth) columns of this table present the results of pooled cross-sectional probit models (general linear models with logistic link functions) where the dependent variable is an indicator variable for whether the press covers CEO compensation (the percentage of CEO compensation articles that are negative). The sixth column presents the results of a pooled cross-sectional probit model where the dependent variable is an indicator variable for whether there is negative coverage of CEO compensation. The seventh column presents results of a pooled crosssectional Poisson regression where the dependent variable is the count of negative publicity articles. Coverage ${ }_{t+1}$ is an indicator variable for whether the press covers CEO compensation. \% of Negative Articles $_{t+1}$ is Number of Negative Articles ${ }_{t+1}$ divided by Number of Articles $s_{t+1}$, where Number of Negative Articles $s_{t+1}$ is the total number of negative tone articles written about the CEO's compensation, and Number of Articles ${ }_{t+1}$ is the total number of articles written about the CEO's compensation. Negative Coverage Indicator ${ }_{t+1}$ is an indicator variable equal to one if the CEO has negative press coverage in a given year, and zero otherwise. Total Comp $\mathrm{p}_{\mathrm{t}}$ is salary, bonus, long-term incentive plan payouts, value of restricted stock grants, value of option grants during year $t$, and any other annual pay during year t. Residual(Total Comp ${ }_{t}$ ) is residual Total Comp $\mathrm{t}_{\mathrm{t}}$ computed using equation (5) and based on the linear regression model shown in Table 4. Expected(Total Comp $\mathrm{p}_{t}$ ) is Total Comp $\mathrm{p}_{\mathrm{t}}-$ Residual(Total Comp $\mathrm{t}_{\mathrm{t}}$. Compensation amounts are in millions of dollars. $\log (\text { Number of Firm Articles })_{t+1}$ is the logarithm of the number of articles written about the firm during year $t+1 . \log (\text { Tenure })_{t}$ is the logarithm of CEO's tenure in years at the end of the year plus $+0.1 . \mathrm{S} \& \mathrm{P} 500_{\mathrm{t}}$ is one if the firm is in the S\&P500 at the end of the year, and zero otherwise. $\log \left(\right.$ Sales $\left._{t}\right)$ is the logarithm of firm sales for year t. RET is the firm's return for the year. POSRET (NEGRET) is RET if positive (negative), and zero otherwise. ROA is income before extraordinary items divided by average total assets for the year $t+1$. POSROA (NEGROA) is ROA if positive (negative), and zero otherwise. Fixed effects for year and 2-digit SIC codes are included in the regressions, but not tabulated. T-statistics using the Huber-White robust standard errors are presented in parentheses below coefficient estimates. ${ }^{*},{ }^{*}$, and ${ }^{* * *}$ indicate two-tailed statistical significance at 10,5 , and 1 percent levels, respectively.

\begin{tabular}{|c|c|c|c|c|c|c|c|}
\hline & \multicolumn{7}{|c|}{ Dependent Variable: } \\
\hline & Coverage $_{t+1}$ & $\begin{array}{c}\text { \% of } \\
\text { Negative }^{\text {Articles }}{ }_{\mathrm{t}+1}\end{array}$ & Coverage $_{t+1}$ & $\begin{array}{c}\text { \% of } \\
\text { Negative }^{\text {Articles }} \\
\text { tr+1 }^{2}\end{array}$ & $\begin{array}{c}\text { \% of } \\
\text { Negative }^{\text {Articles }}{ }_{t+1}\end{array}$ & $\begin{array}{l}\text { Negative } \\
\text { Coverage } \\
\text { Indicator }_{t+1}\end{array}$ & $\begin{array}{c}\text { Number } \\
\text { of } \\
\text { Negative } \\
\text { Articles }_{t+1}\end{array}$ \\
\hline Independent Variable & $(1)$ & $(2)$ & (3) & (4) & $(5)$ & (6) & $(7)$ \\
\hline Total Comp & $\begin{array}{c}0.021 * * * \\
(6.10)\end{array}$ & $\begin{array}{c}0.015^{* * *} \\
(3.58)\end{array}$ & & & & & \\
\hline Residual(Total Comp) $)_{\mathrm{t}}$ & & & $\begin{array}{c}0.020 * * * \\
(5.15)\end{array}$ & $\begin{array}{c}0.024 * * * \\
(4.15)\end{array}$ & $\begin{array}{c}0.021 * * * \\
\quad(3.60)\end{array}$ & $\begin{array}{c}0.026^{* * * *} \\
\quad(6.21)\end{array}$ & $\begin{array}{c}0.028 * * * \\
\quad(6.98)\end{array}$ \\
\hline Expected(Total Comp) $)_{t}$ & & & $\begin{array}{c}0.028 * * * \\
(4.41)\end{array}$ & $\begin{array}{l}-0.013 \\
(-1.13)\end{array}$ & $\begin{array}{l}0.0004 \\
(0.06)\end{array}$ & $\begin{array}{l}0.012 \\
(1.62)\end{array}$ & $\begin{array}{c}0.000 \\
(-0.06)\end{array}$ \\
\hline $\log (\text { Number of Firm Articles })_{t+1}$ & $\begin{array}{c}0.364 * * * \\
(17.72)\end{array}$ & $\begin{array}{l}0.042 \\
(0.95)\end{array}$ & $\begin{array}{c}0.362 * * * \\
(17.51)\end{array}$ & $\begin{array}{l}0.064 \\
(1.50)\end{array}$ & & $\begin{array}{c}0.350 * * * \\
(10.10)\end{array}$ & $\begin{array}{c}0.609 * * * \\
(10.67)\end{array}$ \\
\hline $\log (\text { Tenure })_{\mathrm{t}}$ & $\begin{array}{c}0.056^{* * * *} \\
(2.79)\end{array}$ & $\begin{array}{l}0.008 \\
(0.22)\end{array}$ & $\begin{array}{c}0.057 * * * \\
(2.82)\end{array}$ & $\begin{array}{l}0.005 \\
(0.15)\end{array}$ & & $\begin{array}{c}0.068 * * * \\
(3.13)\end{array}$ & $\begin{array}{c}0.132 * * * \\
(4.30)\end{array}$ \\
\hline $\log (\text { Sales })_{t}$ & $\begin{array}{c}0.178 * * * \\
(6.29)\end{array}$ & $\begin{array}{l}0.001 \\
(0.03)\end{array}$ & $\begin{array}{c}0.169 * * * \\
(5.95)\end{array}$ & $\begin{array}{l}0.054 \\
(0.85)\end{array}$ & & $\begin{array}{c}0.211 * * * \\
\quad(5.19)\end{array}$ & $\begin{array}{c}0.397 * * * \\
(5.71)\end{array}$ \\
\hline $\mathrm{S} \& \mathrm{P} 500_{\mathrm{t}}$ & $0.163^{* *}$ & -0.044 & $0.151 * *$ & -0.001 & & 0.078 & 0.101 \\
\hline
\end{tabular}




\begin{tabular}{|c|c|c|c|c|c|c|c|}
\hline POSRET $_{t+1}$ & $\begin{array}{l}0.023 \\
(0.81)\end{array}$ & $\begin{array}{c}-0.391 * * * \\
(-2.96)\end{array}$ & $\begin{array}{l}0.025 \\
(0.86)\end{array}$ & $\begin{array}{c}-0.406^{* * * *} \\
(-3.02)\end{array}$ & & $\begin{array}{c}-0.165 * * * \\
(-2.66)\end{array}$ & $\begin{array}{l}-0.109 \\
(-1.16)\end{array}$ \\
\hline NEGRET $_{t+1}$ & $\begin{array}{c}0.159^{*} \\
(1.68)\end{array}$ & $\begin{array}{c}0.671^{* * *} \\
(3.19)\end{array}$ & $\begin{array}{l}0.161^{*} \\
(1.70)\end{array}$ & $\begin{array}{c}0.670^{* * *} \\
(3.12)\end{array}$ & & $\begin{array}{c}0.387 * * * \\
(3.75)\end{array}$ & $\begin{array}{l}-0.104 \\
(-0.47)\end{array}$ \\
\hline POSRET $_{t}$ & $\begin{array}{l}0.026 \\
(0.82)\end{array}$ & $\begin{array}{l}-0.006 \\
(-0.05)\end{array}$ & $\begin{array}{l}0.022 \\
(0.70)\end{array}$ & $\begin{array}{l}0.012 \\
(0.10)\end{array}$ & & $\begin{array}{l}0.045 \\
(1.23)\end{array}$ & $\begin{array}{l}0.088 \\
(0.88)\end{array}$ \\
\hline NEGRET $_{t}$ & $\begin{array}{l}0.005 \\
(0.04)\end{array}$ & $\begin{array}{l}0.112 \\
(0.34)\end{array}$ & $\begin{array}{l}0.003 \\
(0.03)\end{array}$ & $\begin{array}{l}0.095 \\
(0.29)\end{array}$ & & $\begin{array}{l}-0.071 \\
(-0.53)\end{array}$ & $\begin{array}{l}-0.406^{*} \\
(-1.74)\end{array}$ \\
\hline POSROA $_{t+1}$ & $\begin{array}{l}-0.191 \\
(-0.42)\end{array}$ & $\begin{array}{l}0.294 \\
(0.27)\end{array}$ & $\begin{array}{l}-0.216 \\
(-0.48)\end{array}$ & $\begin{array}{l}0.463 \\
(0.43)\end{array}$ & & $\begin{array}{l}-0.252 \\
(-0.53)\end{array}$ & $\begin{array}{l}0.758 \\
(1.13)\end{array}$ \\
\hline NEGROA $_{t+1}$ & $\begin{array}{c}-0.602 * * \\
(-2.10)\end{array}$ & $\begin{array}{l}-0.419 \\
(-0.54)\end{array}$ & $\begin{array}{c}-0.594 * * \\
(-2.08)\end{array}$ & $\begin{array}{l}-0.540 \\
(-0.69)\end{array}$ & & $\begin{array}{c}-0.764^{* * *} \\
(-3.11)\end{array}$ & $\begin{array}{c}-0.822^{* *} \\
(-1.98)\end{array}$ \\
\hline POSROA $_{t}$ & $\begin{array}{l}0.508 \\
(1.15)\end{array}$ & $\begin{array}{l}-0.387 \\
(-0.36)\end{array}$ & $\begin{array}{l}0.471 \\
(1.05)\end{array}$ & $\begin{array}{l}-0.144 \\
(-0.14)\end{array}$ & & $\begin{array}{l}0.522 \\
(1.06)\end{array}$ & $\begin{array}{l}-0.427 \\
(-0.37)\end{array}$ \\
\hline $\mathrm{NEGROA}_{\mathrm{t}}$ & $\begin{array}{c}-0.753 * * * \\
(-2.86)\end{array}$ & $\begin{array}{l}0.309 \\
(0.26)\end{array}$ & $\begin{array}{c}-0.725 * * * \\
(-2.68)\end{array}$ & $\begin{array}{l}-0.144 \\
(-0.14)\end{array}$ & & $\begin{array}{l}-0.790 \\
(-1.50)\end{array}$ & $\begin{array}{l}-0.864 \\
(-1.12)\end{array}$ \\
\hline $\mathrm{N}$ & 12,090 & 2,607 & 12,090 & 2,607 & 2,607 & 12,090 & 12,090 \\
\hline $\begin{array}{l}\text { Pseudo } \mathrm{R}^{2} \\
\text { log likelihood }\end{array}$ & 0.2791 & $-1,331.5$ & 0.2792 & $-1,329.0$ & $-1,381.9$ & 0.2924 & 0.3996 \\
\hline
\end{tabular}




\section{Table 7}

\section{Estimates of the Determinants of Negative Publicity and "True” Negative Publicity}

For the analysis in Column (1), the sample consists of 2,607 observations for ExecuComp CEOs with press coverage on compensation from fiscal years 1993 to 2001. The table shows estimation results of pooled cross-sectional general linear models, where the dependent variable is the percentage of CEO compensation articles that are negative. The articles on CEO compensation are obtained from the Factiva database for years 1994 to 2002 and coded as negative using the algorithm described in the text. Column (1) is the same as the results reported in Column (4) of Table 6. The sub-sample in Column (2) consists of 175 observations randomly selected from Column (1) where the articles are coded as negative using the algorithm described in the text. The sub-sample in Column (3) consists of the same 175 random observations from Column (2), but for which the negative tone was manually coded. The dependent variable in all regressions is the percentage of CEO compensation articles that are negative. Total Comp $\mathrm{t}_{\mathrm{t}}$ is salary, bonus, long-term incentive plan payouts, the value of restricted stock grants, the value of options granted during year $\mathrm{t}$, and any other annual pay for the CEO in year t. Residual(Total Compt $\mathrm{t}_{\mathrm{t}}$ ) is residual Total Comp $\mathrm{t}_{\mathrm{t}}$ computed using equation (5) and based on the linear regression model shown in Table 4. Expected(Total Comp $\mathrm{p}_{\mathrm{t}}$ ) is Total Comp $\mathrm{t}_{\mathrm{t}}$ - Residual(Total Comp $\mathrm{t}_{\mathrm{t}}$. Compensation amounts are in millions of dollars. Fixed effects for year and 2-digit SIC codes are included in the regressions, but not tabulated. T-statistics using the Huber-White robust standard errors are presented in parentheses below coefficient estimates. *, **, and *** indicate two-tailed statistical significance at 10,5, and 1 percent levels, respectively.

\begin{tabular}{|c|c|c|c|}
\hline & $\begin{array}{c}\text { Full Sample: } \\
\% \text { of Negative Articles } \text { t+1 }\end{array}$ & $\begin{array}{c}\text { Sub-Sample: } \\
\% \text { of Negative Articles }{ }_{t+1}\end{array}$ & $\begin{array}{c}\text { Sub-Sample: } \\
\text { “True” \% of } \\
\text { Negative } \\
\text { Articles }_{t+1}\end{array}$ \\
\hline Independent Variable & (1) & $(2)$ & (3) \\
\hline Residual(Total Comp)t & $\begin{array}{c}0.024 * * * \\
(4.15)\end{array}$ & $\begin{array}{c}0.033^{* *} \\
(2.25)\end{array}$ & $\begin{array}{c}0.063^{* *} \\
(1.98)\end{array}$ \\
\hline Expected(Total Comp) $)_{t}$ & $\begin{array}{l}-0.013 \\
(-1.13) \\
\end{array}$ & $\begin{array}{l}-0.003 \\
(-0.07) \\
\end{array}$ & $\begin{array}{l}0.020 \\
(0.15) \\
\end{array}$ \\
\hline $\log (\text { Articles })_{t+1}$ & $\begin{array}{l}0.064 \\
(1.50)\end{array}$ & $\begin{array}{l}0.051 \\
(0.15)\end{array}$ & $\begin{array}{l}-0.812^{*} \\
(-1.88)\end{array}$ \\
\hline $\log (\text { Tenure })_{t}$ & $\begin{array}{l}0.005 \\
(0.15)\end{array}$ & $\begin{array}{l}-0.216 \\
(-1.21)\end{array}$ & $\begin{array}{l}-0.048 \\
(-0.16)\end{array}$ \\
\hline $\log (\text { Sales })_{\mathrm{t}}$ & $\begin{array}{l}0.054 \\
(0.85)\end{array}$ & $\begin{array}{l}0.171 \\
(0.74)\end{array}$ & $\begin{array}{l}0.836 \\
(1.37)\end{array}$ \\
\hline$S \& P 500_{t}$ & $\begin{array}{l}-0.001 \\
(0.00)\end{array}$ & $\begin{array}{l}-0.200 \\
(-0.55)\end{array}$ & $\begin{array}{c}3.686^{* * * *} \\
(4.21)\end{array}$ \\
\hline POSRET $_{t+1}$ & $\begin{array}{c}-0.406^{* * *} \\
(-3.02)\end{array}$ & $\begin{array}{l}-0.350 \\
(-0.94)\end{array}$ & $\begin{array}{l}-0.430 \\
(-0.28)\end{array}$ \\
\hline NEGRET $_{\mathrm{t}+1}$ & $\begin{array}{c}0.670 * * * \\
(3.12)\end{array}$ & $\begin{array}{c}2.205 * * * \\
(3.22)\end{array}$ & $\begin{array}{l}1.623 \\
(1.20)\end{array}$ \\
\hline POSRET $_{t}$ & $\begin{array}{l}0.012 \\
(0.10)\end{array}$ & $\begin{array}{l}0.269 \\
(0.83)\end{array}$ & $\begin{array}{l}0.572 \\
(0.80)\end{array}$ \\
\hline
\end{tabular}




\begin{tabular}{lccc} 
NEGRET $_{\mathrm{t}}$ & 0.095 & -1.449 & -2.707 \\
& $(0.29)$ & $(-1.20)$ & $(-1.59)$ \\
POSROA $_{\mathrm{t}+1}$ & 0.463 & 4.763 & 10.867 \\
& $(0.43)$ & $(1.54)$ & $(0.87)$ \\
NEGROA $_{\mathrm{t}+1}$ & -0.540 & -2.114 & $-9.599^{* * *}$ \\
& $(-0.69)$ & $(-1.53)$ & $(-3.16)$ \\
POSROA $_{\mathrm{t}}$ & -0.144 & $-8.787^{* * *}$ & $-13.416^{* *}$ \\
& $(-0.14)$ & $(-2.91)$ & $(-2.05)$ \\
NEGROA $_{\mathrm{t}}$ & -0.144 & 2.641 & -0.961 \\
& $(-0.14)$ & $(1.30)$ & $(-0.29)$ \\
\hline $\mathrm{N}$ & 2,607 & 175 & 175 \\
$\log$ likelihood & $-1,329.0$ & -64.1 & -23.8 \\
\hline \hline
\end{tabular}




\section{Table 8}

\section{Estimates of the Determinants of the Negative Publicity Ratio: Multiple Measures of Excess Pay Included Simultaneously}

The sample for the negative publicity ratio consists of 2,607 observations for ЕxecuComp CEOs from fiscal years 1993 to 2001. The articles on CEO compensation are obtained from the Factiva database for years 1994 to 2002. The columns present the results of pooled cross-sectional general linear models regressions where the dependent variable is the percentage of CEO compensation articles that have a negative tone. $\%$ of Negative Articles $t_{t+1}$ is Number of Negative Articles $\mathrm{t}_{t+1}$ divided by Number of Articles $_{t+1}$, where Number of Negative Articles ${ }_{t+1}$ is the total number of negative tone articles written about the CEO's compensation, and Number of Articles $t_{t+1}$ is the total number of articles written about the CEO's compensation. Total Comp $\mathrm{t}_{\mathrm{t}}$ is salary, bonus, long-term incentive plan payouts, the value of restricted stock grants, the value of options granted during the year, and any other annual pay for the CEO in year $t$. Total Payout $t_{t}$ is salary, bonus, long-term incentive plan payouts, the value of restricted stock grants, the proceeds from options exercised during the year, and any other annual pay for the CEO in year $t$. Residual(Total Comp) and Residual(Total Payout) are the residual for each compensation variable computed using equation (4). Compensation amounts are in millions of dollars. \%Residual(Total Comp) is the percentage of residuals computed using equation (5). All of the control variables shown in Table 6 are included in the regressions, but not tabulated. Fixed effects for year and 2-digit SIC codes are included in the regressions, but not tabulated. Tstatistics using the Huber-White robust standard errors are presented in parentheses below coefficient estimates. *, $* *$, and $* * *$ indicate two-tailed statistical significance at 10,5 , and 1 percent levels, respectively.

\begin{tabular}{|c|c|c|c|c|c|}
\hline \multirow[b]{2}{*}{ Independent Variable } & \multicolumn{5}{|c|}{$\%$ of Negative Articles ${ }_{t+1}$} \\
\hline & $(1)$ & $(2)$ & (3) & $(4)$ & $(5)$ \\
\hline Residual(Total Comp ${ }_{t}$ ) & $\begin{array}{c}0.022 * * * \\
(4.09)\end{array}$ & $\begin{array}{c}0.017 * * * \\
(3.35)\end{array}$ & $\begin{array}{c}0.015 * * * \\
(3.06)\end{array}$ & $\begin{array}{c}0.019 * * * \\
(2.91)\end{array}$ & $\begin{array}{c}0.022 * * * \\
(3.21)\end{array}$ \\
\hline Total Payout $_{t}$ & & $\begin{array}{c}0.008^{*} \\
(1.93)\end{array}$ & & & \\
\hline Residual(Total Payout $\left.t_{t}\right)$ & & & $\begin{array}{c}0.013 * * * \\
(2.58)\end{array}$ & $\begin{array}{l}0.012^{*} \\
(1.90)\end{array}$ & \\
\hline Residual(Total Comp $\mathrm{t}_{\mathrm{t}-1}$ ) & & & & $\begin{array}{c}0.008^{* * *} \\
(1.35)\end{array}$ & \\
\hline Residual(Total Comp $\mathrm{t}_{\mathrm{t}-2}$ ) & & & & $\begin{array}{c}0.018^{* * * *} \\
(2.30)\end{array}$ & \\
\hline$\%$ Residual(Total Comp $\mathrm{t}$ ) & & & & & $\begin{array}{l}0.008 \\
(0.12)\end{array}$ \\
\hline $\mathrm{N}$ & 2,607 & 2,607 & 2,607 & 1,683 & 2,607 \\
\hline log likelihood & $-1,329.4$ & $-1,328.1$ & $-1,327.3$ & -837.2 & $-1,329.4$ \\
\hline
\end{tabular}


Table 9

\section{Analysis of Changes in Excess Pay and CEO Turnover Following Negative Publicity}

This table presents the results of pooled cross-sectional OLS regressions (a logit regression) where the dependent variable is the change in compensation from year $t$ to $t+2$ (CEO turnover in year $t+2)$, and the primary independent variable of interest is unexpected negative publicity. The sample for the compensation change analysis consists of observations for all ExecuComp CEOs from fiscal years 1993 to 2001 where the CEO has compensation data for year $\mathrm{t}$ and year $\mathrm{t}+2$ pay (8,803 observations), and the sample for the turnover consists of observations for all ExecuComp CEOs from fiscal years 1993 to 2001 where the CEO has compensation data for year $t$ and where the $\mathrm{CEO}$ is in place at the start of year $\mathrm{t}+1$ pay $\left(10,431\right.$ observations). Total Comp $\mathrm{p}_{\mathrm{t}}$ is salary, bonus, long-term incentive plan payouts, the value of restricted stock grants, the value of options granted during the year, and any other annual pay for the CEO in year t. Total Payout $t_{t}$ is salary, bonus, long-term incentive plan payouts, the value of restricted stock grants, the proceeds from options exercised during the year, and any other annual pay for the CEO in year $t$. \%Residual(Total Comp) and \%Residual(Total Payout) are the residual for each compensation variable computed using equation (5). For Total Comp and Total Payout, the Change in \%Residual(X) variable is computed as $\%$ Residual $\left(\mathrm{X}_{\mathrm{t}+2}\right)-\%$ Residual $\left(\mathrm{X}_{\mathrm{t}}\right)$. Negative Publicity $\mathrm{t}_{\mathrm{t}+1}=\%$ of Negative Articles $\mathrm{t}_{\mathrm{t}+1}$ if Coverage $=1$, and 0 otherwise. Unexpected Negative Publicity $y_{t+1}$ is Negative Publicity ${ }_{t+1}$ less the expected component due to firm and $\mathrm{CEO}$ characteristics other than compensation. Industry-adjusted $\mathrm{RET}_{\mathrm{t}+1}$ is the firm's return for the year $\mathrm{t}+1$, less the return for the median firm in that firm's two-digit SIC code for the year. Industry-adjusted $\mathrm{ROA}_{t+1}$ is income before extraordinary items divided by average total assets for the year $\mathrm{t}+1$, less the ROA for the median firm in that firm's two-digit SIC code for the year. $\log \left(\right.$ Sales $\left._{t+1}\right)$ is the natural logarithm of firm sales. CEO is 64 or older $_{t+1}$ is equal to one if the CEO is 64 or older, and zero otherwise. Fixed effects for year are included in the regression, but not tabulated. T-statistics using Huber-White robust standard errors are presented in parentheses below coefficient estimates. ${ }^{*}, * *$, and $* * *$ indicate two-tailed statistical significance at 10,5 , and 1 percent levels, respectively.

\begin{tabular}{|c|c|c|c|c|c|}
\hline & $\begin{array}{c}\text { Change in } \\
\text { \%Residual(Total } \\
\text { Comp) })_{t+2} \\
\end{array}$ & $\begin{array}{c}\text { Change in } \\
\text { \%Residual(Total } \\
\text { Comp) })_{t+2} \\
\end{array}$ & $\begin{array}{c}\text { Change in } \\
\text { \%Residual(Total } \\
\text { Comp) })_{t+2} \\
\end{array}$ & $\begin{array}{c}\text { CEO } \\
\text { Turnover } \\
t+2 \\
\end{array}$ & $\begin{array}{c}\text { Change in } \\
\text { \%Residual(Total } \\
\text { Payout) })_{t+2} \\
\end{array}$ \\
\hline Independent Variable & $(1)$ & $(2)$ & (3) & (4) & (5) \\
\hline Negative Publicity $_{t+1}$ & $\begin{array}{c}-0.078^{* *} \\
(-2.45)\end{array}$ & $\begin{array}{l}0.032 \\
(1.05)\end{array}$ & & & \\
\hline $\begin{array}{l}\text { Unexpected } \\
\text { Negative Publicity }{ }_{t+1}\end{array}$ & & & $\begin{array}{l}0.002 \\
(0.06)\end{array}$ & $\begin{array}{l}-0.080 \\
(-0.63)\end{array}$ & $\begin{array}{l}-0.018 \\
(-0.41)\end{array}$ \\
\hline 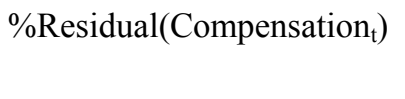 & & $\begin{array}{l}-0.483 * * * \\
(-28.24)\end{array}$ & $\begin{array}{c}-0.482^{* * *} \\
(-28.54)\end{array}$ & & $\begin{array}{c}-0.542^{* * *} \\
(-24.37)\end{array}$ \\
\hline Ind-Adj. $\mathrm{RET}_{\mathrm{t}+1}$ & & & & $\begin{array}{c}-0.632 * * * \\
(-8.16)\end{array}$ & \\
\hline Ind-Adj. $\mathrm{ROA}_{\mathrm{t}+1}$ & & & & $\begin{array}{c}-1.955 * * * \\
(-3.59)\end{array}$ & \\
\hline $\log (\text { Sales })_{t+1}$ & & & & $\begin{array}{c}0.096 * * * \\
(3.80)\end{array}$ & \\
\hline CEO is 64 or older ${ }_{t+1}$ & & & & $\begin{array}{c}0.936^{* * * *} \\
(11.42)\end{array}$ & \\
\hline $\mathrm{N}$ & 8,791 & 8,791 & 8,791 & 10,431 & 8,791 \\
\hline Number of Turnovers & & & & 1,566 & \\
\hline $\mathrm{R}^{2}$ & 0.0022 & 0.2533 & 0.2531 & & 0.2620 \\
\hline Pseudo- $\mathrm{R}^{2}$ & & & & 0.0411 & \\
\hline
\end{tabular}

